\title{
Allopatric cryptic diversity in the alpine species complex Phtheochroa frigidana s. lat. (Lepidoptera: Tortricidae)
}

\author{
Boyan ZLATKOV ${ }^{1, *} \&$ Peter HUEMER ${ }^{2}$ \\ ${ }^{1}$ Institute of Biodiversity and Ecosystem Research, Bulgarian Academy of Sciences, \\ 1 Tsar Osvoboditel Blvd, 1000 Sofia, Bulgaria. \\ ${ }^{1}$ National Museum of Natural History, Bulgarian Academy of Sciences, \\ 1 Tsar Osvoboditel Blvd, 1000 Sofia, Bulgaria. \\ ${ }^{2}$ Tiroler Landesmuseen Betriebsgesellschaft m.b.H., Sammlungs- und Forschungszentrum, \\ Naturwissenschaftliche Sammlungen, Krajnc-Str. 1, A-6060 Hall in Tirol, Austria. \\ *Corresponding author: bzlatkov@gmail.com \\ 2Email: p.huemer@tiroler-landesmuseen.at \\ ${ }^{1}$ urn:1sid:zoobank.org:author:3538D3F5-6822-403F-B9E6-E8A95E884404 \\ ${ }^{2}$ urn:1sid:zoobank.org:author:4E6F001E-DB9D-460C-AB39-0CE7CC773B59
}

\begin{abstract}
Allopatric alpine populations of Phtheochroa frigidana s. lat. (Lepidoptera, Tortricidae) are reviewed. In addition to traditional diagnostic characters of external morphology, the genitalia structures of everted vesicae in male genitalia and DNA barcodes are analysed. This new approach supports the existence of five rather than two species in Europe: Phtheochroa schawerdae (Rebel, 1908) comb. nov. (Dinaric Mts, Rila Mts, Pirin Mts) $=$ P. drenowskyi (Rebel, 1916) syn. nov.; P. alpinana sp. nov. (SW Alps); P. apenninana sp. nov. (Apennines); P. frigidana (Guenée, 1845) stat. rev. (Pyrenees) $=P$. flavidana $($ Guenée, 1845) $=P$. sulphurana $($ Guenée, 1845) $=P$. andorrana (Millière, 1865); P. cantabriana sp. nov. (Cantabrian Mts). In order to stabilize the nomenclature, a neotype for Eupoecilia frigidana is designated.
\end{abstract}

Keywords. Lepidoptera, Phtheochroa frigidana, species complex, revised taxonomy, DNA barcoding.

Zlatkov B. \& Huemer P. 2017. Allopatric cryptic diversity in the alpine species complex Phtheochroa frigidana s. lat. (Lepidoptera: Tortricidae). European Journal of Taxonomy 368: 1-25. https://doi.org/10.5852/ejt.2017.368

\section{Introduction}

Phtheochroa frigidana s. lat. is an example of an alpine species with a pattern of disjunct, allopatric populations in major European mountain systems. Similar cases are found in several other genera in various families of Lepidoptera, e.g., Kessleria Nowicki, 1864 (Yponomeutidae), Sattleria Povolný, 1965 (Gelechiidae), Sphaleroptera Guenée, 1845 (Tortricidae), Orenaia Duponchel, 1845 (Crambidae), Erebia Dalman, 1816(Nymphalidae), Elophos Boisduval, 1840 (Geometridae) and Agrotis Ochsenheimer, 1816 (Noctuidae). The taxonomy in many of these taxa is disputed and different species concepts have been applied by various authors. Modern molecular studies (Hebert et al. 2003, 2009) have helped to resolve some of the critical issues (Huemer \& Hebert 2011; Huemer \& Mutanen 2015), although others have remained unresolved (Mutanen et al. 2012). 
Widespread though disjunct species such as Phtheochroa frigidana (Guenée, 1845) stat. rev. are subject to isolation in their alpine environment, resulting in interrupted gene-flow. They therefore deserve particular attention as model groups of potential speciation processes. Literature sources suggest that $P$. frigidana is distributed at high altitudes in the Apennines, the south-western Alps, the Pyrenees and the Dinaric Mts. The closely related sister species P. drenowskyi (Rebel, 1916) has been reported from the Apennines, the Dinaric Mts, the Carpathian Mts and the Rila Mts (Razowski 2009; Trematerra 2003; Kovács \& Kovács 2004), thus in putative sympatry with P. frigidana. However, initial DNA barcoding of specimens from the Cantabrian Mts and from the Pyrenees to the Balkan Peninsula indicated quite a different taxonomy.

We therefore revise the group, introducing for the first time new morphological techniques for species delimitation, particularly eversion of the vesica in the male genitalia and analysis of the COI standard barcode region of the mitochondrial DNA.

\section{Material and methods}

We examined 38 specimens of the P. frigidana species group. The moths collected by the authors were pinned and partially spread or prepared following standard techniques. The genitalia were processed following the methodology of Robinson (1976) and Zlatkov (2011). The phalli with everted vesicae were submerged in Euparal essence on a cavity slide, immobilized with a curved minute needle inserted through the phallic opening, and drawn under a compound microscope with camera lucida attached. The phalli were observed and drawn from two aspects: dorsal and left. Only completely everted and maximally inflated vesicae were used. The angles of the diverticula were measured from drawings and photographs with a protractor. The description of cornuti follows the terminology of Anzaldo et al. 2014; wing pattern elements are those defined by Razowski (2008).

DNA barcode sequences of the mitochondrial COI gene (cytochrome $c$ oxidase 1) were obtained from 11 specimens. DNA samples from dried legs were prepared according to prescribed standards using the high-throughput protocol of deWaard et al. (2008). Samples were processed at the Canadian Centre for DNA Barcoding (CCDB, Biodiversity Institute of Ontario, University of Guelph) to obtain DNA barcodes (Ratnasingham \& Hebert 2007). DNA sequencing resulted in a full barcode fragment of 658 $\mathrm{bp}$ for eight specimens and a further three sequences with 632, 628 and $612 \mathrm{bp}$. Details of successfully sequenced voucher specimens, including complete voucher data and images, can be accessed in the Barcode of Life Data Systems (Ratnasingham \& Hebert 2007). Degrees of intra- and interspecific variation in the DNA barcode fragments were calculated under the Kimura 2 parameter (K2P) model of nucleotide substitution using analytical tools in BOLD systems v. 3.0 (http://www.boldsystems.org). A maximum likelihood (ML) tree of the DNA barcode data was constructed using MEGA 6 (Tamura et al. 2013) under the GTR + G model for nucleotide substitutions. Node support values were estimated based on 500 bootstrap replicates.

Material from public and private collections was examined. The acronyms used in the text are as follows:

$$
\begin{array}{ll}
\text { BFUS } & =\text { Zoological collection of the Faculty of Biology, Sofia University, Bulgaria } \\
\text { JJ } & =\text { Private collection of J. Junnilainen, Helsinki, Finland } \\
\text { NMNHS } & =\text { National Museum of Natural History, Sofia, Bulgaria } \\
\text { TLMF } & =\text { Tiroler Landesmuseum Ferdinandeum, Innsbruck, Austria }
\end{array}
$$

Other abbreviations:

a.s.l. $=$ above sea level

Mts $=$ Mountains

Mya $=$ million years ago 


\title{
Results
}

\author{
Class Insecta Linnaeus, 1758 \\ Order Lepidoptera Linnaeus, 1758 \\ Superfamily Tortricoidea Latreille, 1803 \\ Family Tortricidae Latreille, 1803 \\ Subfamily Tortricinae Latreille, 1803 \\ Tribe Cochylini Guenée, 1845
}

Genus Phtheochroa Stephens, 1829

The analysis of genitalia structures of everted vesicae in male genitalia and DNA barcodes revealed the existence of five European species in the Phtheochroa frigidana group. The key to the species is followed by detailed taxonomic descriptions.

\section{Key to the Phtheochroa frigidana species group, based on male genitalia}

1. Vesica with a single long dorsal diverticulum bearing cornutus (Fig. 7A-B). Phallic process straight (Fig. 4H), phallus almost straight.... P. frigidana (Guenée, 1845)

- Vesica with two distinct diverticula, each with cornutus. Phallic process apically curved to the right, phallus curved

2. Vesica with dorsal and ventral diverticulum protruding from its small right part (Fig. 6A-B) ........

- Vesica with right and left diverticulum protruding from its large right part ....

3. Forewing upperside pale yellow, hindwing pale grey. Main part of vesica in lateral left view angular (Fig. 7C). The angle between the axes of phallus and right diverticulum 120-140 (Fig. 7D). Phallic process slender, not strongly curved (Fig. 4I-J) .P. cantabriana sp. nov.

- Forewing upperside ground colour deep yellow, hindwing dark grey (Fig. 1A-D, G). Main part of vesica in lateral left view ovoid or subspherical. The angle between the axes of phallus and right diverticulum usually less than $120^{\circ}$. Phallic process robust

4. The angle between the axes of phallus and right diverticulum a maximum of $90^{\circ}$. The right part of vesica large, heart-shaped in dorsal view (Fig. 6D). Phallic process blunt, curved (Fig. 4F-G)

P. apenninana sp. nov.

- The angle between the axes of phallus and right diverticulum 100-120. The right part of vesica small, not heart-shaped (Fig. 5B, D). Phallic process large, sharp-tipped and strongly curved (Fig. 4A-C) ..P. schawerdae (Rebel, 1908)

Phtheochroa schawerdae (Rebel, 1908) comb. nov.

Figs 1A-D, 2A-B, 3A-B, 4A-C, 5, 8A, 9, 10; Table 1

Conchylis schawerdae Rebel in Schawerda, 1908: 255.

Euxanthis drenowskyi Rebel, 1916: 42. Syn. nov.

Hysterosia drenowskyi - Razowski 1970: 72, pl. 1, fig. 2, pl. 29, fig. 2, pl. 112, fig. 2.

Phtheochroa drenowskyi - Razowski 2002: 38.

non Phtheochroa drenovskyi - Razowski 1991a: 103.

non Phtheochroa drenovskii - Razowski 1991b: 166. 


\section{Diagnosis}

Externally, this species resembles $P$. apenninana sp. nov., with a deep yellow forewing upperside and a dark grey hindwing. The most conspicuous difference can be seen in the vesica: the axes of the right diverticulum and the sclerotized phallus form an angle of $100-120^{\circ}$ in $P$. schawerdae and a maximum of $90^{\circ}$ in $P$. apenninana sp. nov.; the right part of the vesica is larger in $P$. apenninana sp. nov. Other characters of less importance are the shape of the valva (wider in P. schawerdae, more slender in $P$. apenninana sp. nov.) and transtilla (short, with wide base in P. apenninana sp. nov. but variable in $P$. schawerdae). The ventral phallic process is strongly curved to the right, in contrast to all other species of the group. The upperside wing colour easily distinguishes $P$. schawerdae from $P$. alpinana sp. nov., $P$. frigidana and $P$. cantabriana sp. nov.

\section{Material examined}

BULGARIA: 1 đે, Rila Mts, Yurushki chal [Ovcharets] summit, 2100 m a.s.1., 24 Jul. 1907, A. Drenowsky

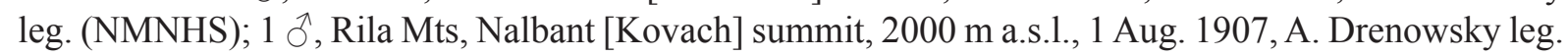

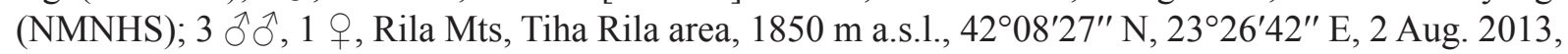

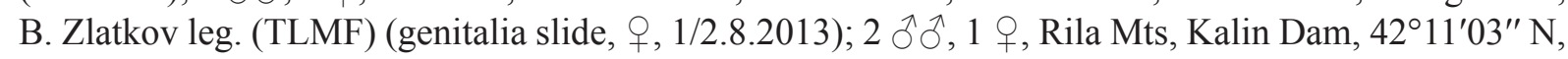
$23^{\circ} 15^{\prime} 42^{\prime \prime}$ E, $2450 \mathrm{~m}$ a.s.1., 20 Aug. 2013, B. Zlatkov leg. (BFUS) (genitalia slide, $\partial^{\lambda}, 1 / 20.8 .2013$ ); 1 ว’,

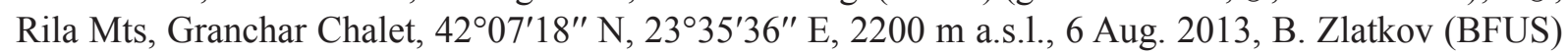

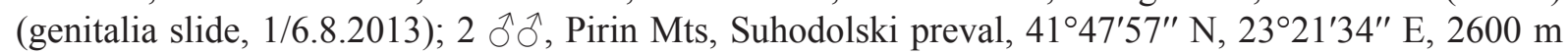
a.s.1., 9 Jul. 2012, B. Zlatkov and O. Sivilov leg. (BFUS).

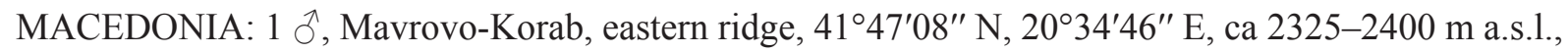
28 Jul.-1 Aug. 2011, Huemer and Tarmann leg. (TLMF) (genitalia slide, 1/28.7-1.8.2011).

\section{Redescription}

Male (Fig. 1A-B, D)

HeAD. Frons and vertex rust yellow. Labial palps pointed anterad, relatively long, dorsally rust yellow, laterally rust. Scapus and pedicellus dorsally rusty, ventrally creamy, flagellum with yellow scales.

THorax. Dorsally, including tegulae, rusty yellow, ventrally, mid- and hindlegs creamy, forelegs rusty. Forewing length 7.3-9.6 mm $(\mathrm{x}=8.1, \mathrm{n}=11)$, upperside deep yellow, rarely rust, with more or less pronounced dorsal blotch, cilia concolourous with wings, underside dark grey, with creamy line in costal area. Hindwing upperside dark grey, cilia pale grey, with darker basal part, underside dark grey, with creamy costal area, sometimes with short white longitudinal line near end of vein $\mathrm{M}_{2}$.

AвDOMEN. Grey with scattered white scales.

Genitalia (Fig. 2A-B). Valva with weak dorsal curvature, round apically, with parallel costa and sacculus, both moderately sclerotized. Valva may appear wider or narrower depending on preparation. Uncus relatively well sclerotized, tapered apically. Socii rounded, convergent and connected medially with membrane. Transtilla (Fig. 3A-B) dorsally spinulous, variably shaped in specimens from same population: apically rounded or relatively angled, wider or narrower. Phallus (Fig. 5) slightly curved ventrally, medioventrally with large, slender, sharp-tipped process (Fig. 4A-C), with apex curved to the right at nearly right angle. Vesica with large main part protruded at right from sclerotized phallus and two large diverticula bearing long, robust cornuti. Small conical, undulating structure (diverticulum) emerges ventrally from main part. Gonopore located dorsally, surrounded by semicylindrical sclerotized plate with minute lentiform tubercles. Main part medially constricted by circular furrow in which gonopore is sunk. Diverticula emerge close to each other from right side, right one straight and directed 
A

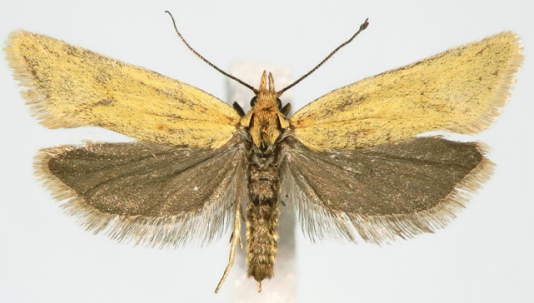

C

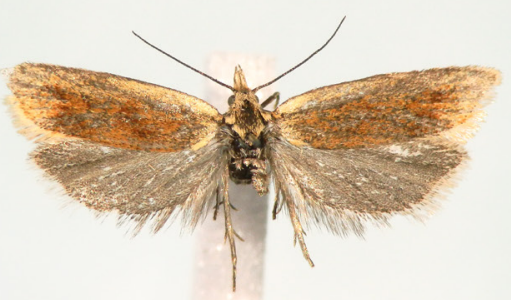

E

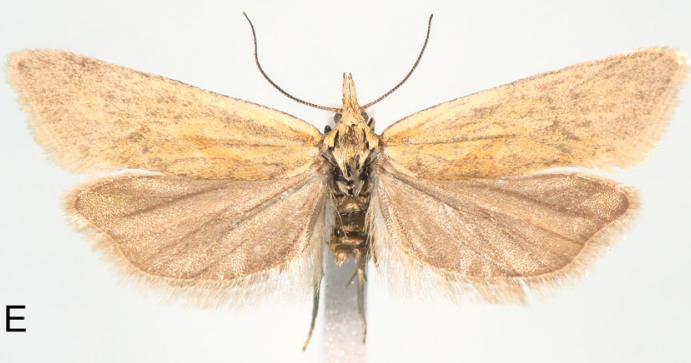

G

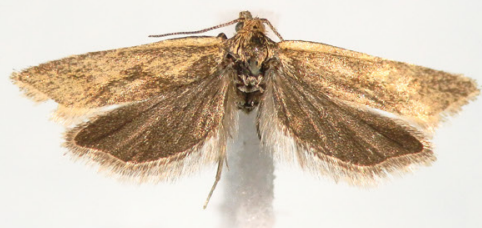

I

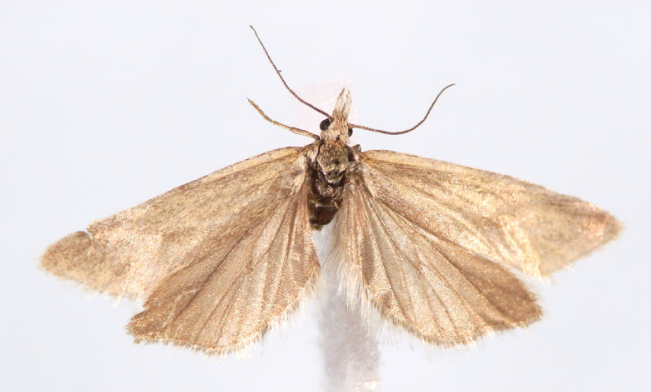

B

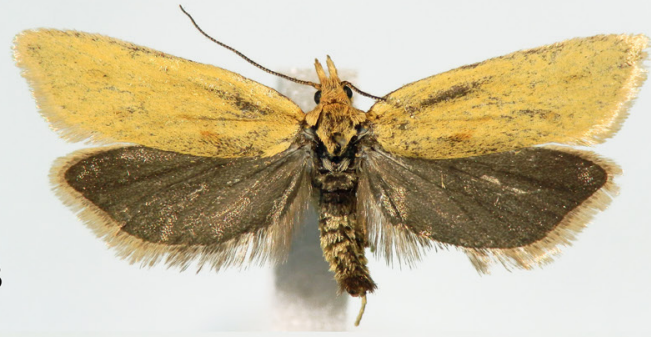

D

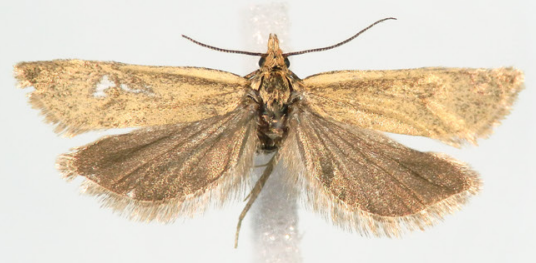

F

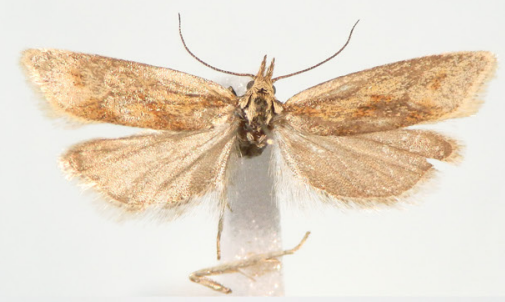

$\mathrm{H}$

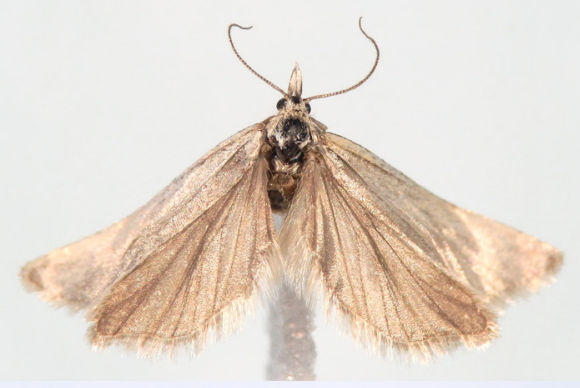

J

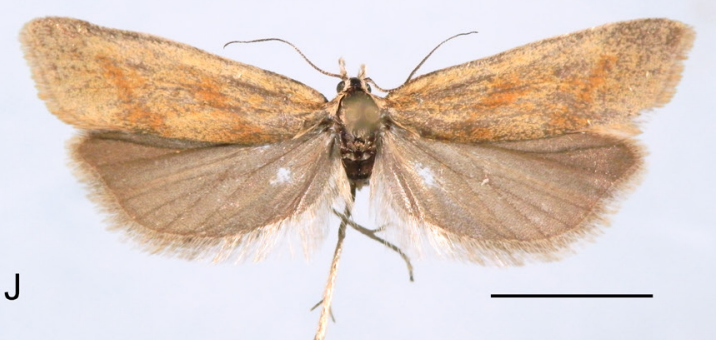

Fig. 1. Adults of Phtheochroa spp. A-D. P. schawerdae (Rebel, 1908) comb. nov. A. ̊̊ , Bulgaria, Pirin

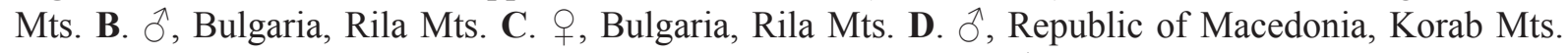
- E-F. P. alpinana sp. nov., France, Alpes Maritimes. E. Holotype, O̊. F. Paratype, , . - G. P. apenninana sp. nov., holotype, đ̂, Italy, Gran Sasso National Park. - H. P. frigidana (Guenée, 1845) stat. rev., ठิ, neotype of Eupoecilia frigidana, Andorra, Pyrenees. - I-J. P. cantabriana sp. nov., Spain, Picos de Europa National Park. I. Holotype, $\widehat{\jmath}$. J. Paratype, $\widehat{\partial}$. Scale bar $=5 \mathrm{~mm}$, all to scale. 
posterolaterally, left one curved and pointed laterally. In lateral left view, main part of vesica looks ovoid or subspherical. Diverticula may vary in width, but their length and orientation are constant. In dorsal view, axes of right diverticulum and sclerotized phallus form angle of 100-120 . Cornuti aciculate,
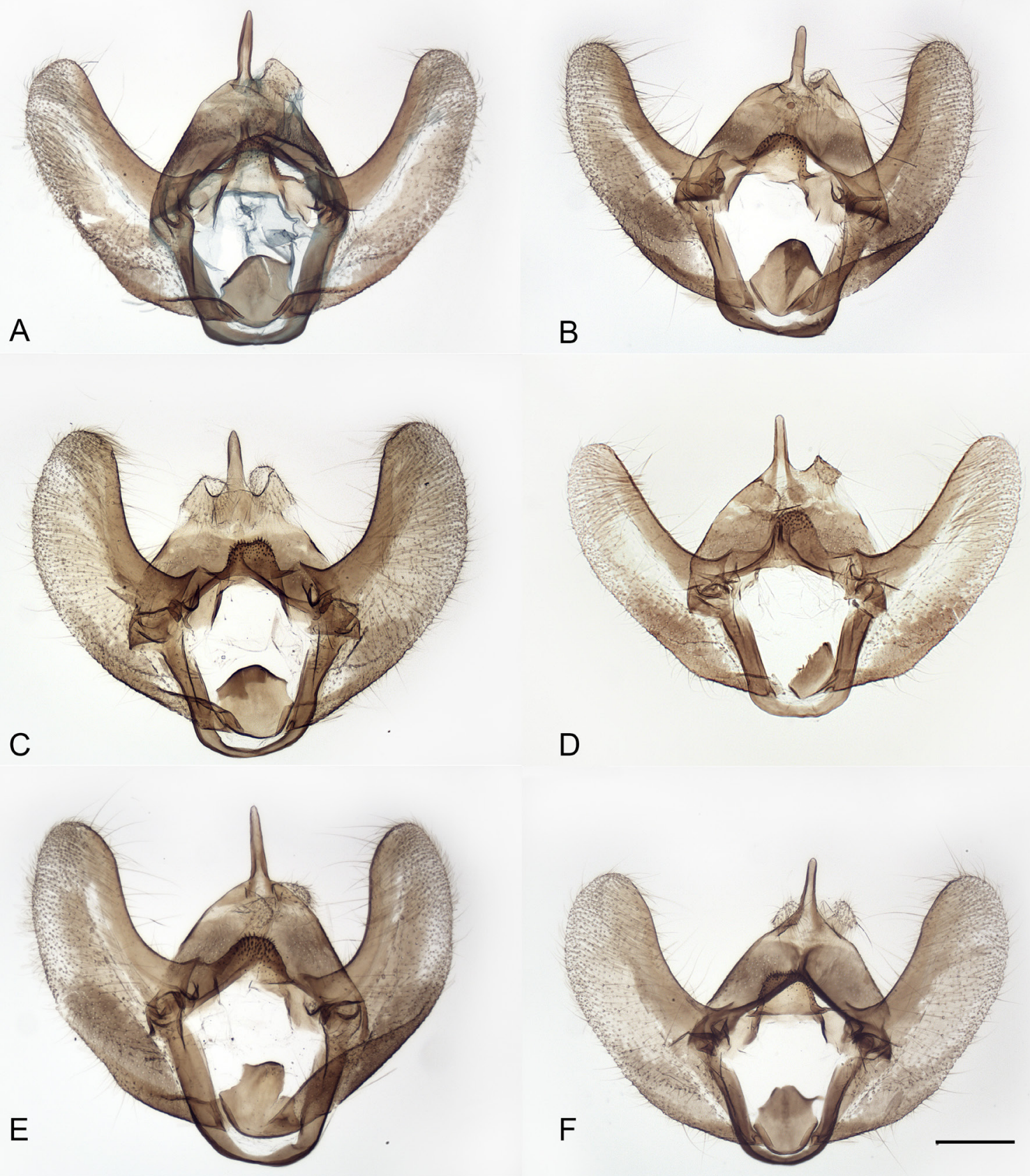

$\mathrm{D}$

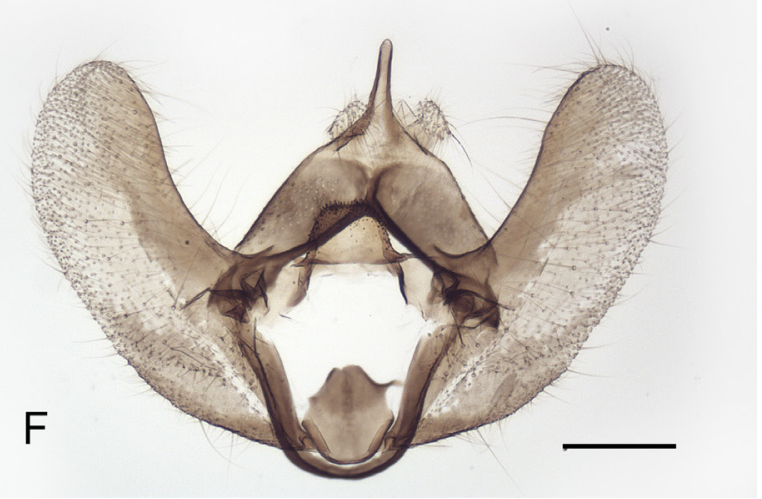

Fig. 2. Male genitalia (without phalli) of Phtheochroa spp. A-B. P. schawerdae (Rebel, 1908) comb. nov. A. Bulgaria, Rila Mts. B. Republic of Macedonia, Korab Mts. - C. P. alpinana sp. nov., France, Alpes Maritimes, holotype. - D. P. apenninana sp. nov., Italy, Gran Sasso National Park, holotype. - E. P. frigidana (Guenée, 1845) stat. rev., Andorra, Pyrenees, neotype of Eupoecilia frigidana. - F. P. cantabriana sp. nov., Spain, Picos de Europa National Park, holotype. Scale bar $=250 \mu \mathrm{m}$, all to scale. 
capitate, of equal length, left one slightly bent. Barely discernible acanthae present on left portion of main part of vesica and at end of diverticula.

\section{Female (Fig. 1C)}

Generally resembles male, but forewing length $7.3-9.2 \mathrm{~mm}(\mathrm{n}=2)$, underside with larger creamy area, hindwing underside creamy or whitish. Female genitalia (Fig. 8A) with tergum 8 medially membranous, sterigma with two lateral protuberances, antrum nearly rectangular, with round anterior angles. Apophyses anteriores longer than apophyses posteriores. Ductus bursae ventrally membranous, with conical diverticulum of thick cuticle curved to the left and triangular sclerite dorsally. Corpus bursae with large sclerite on ventral side forming several (5-6) folds at the right, then expanding medially and dorsally on left side, reaching dorsal area of ductus bursae. Right side of corpus bursae with extensively folded membranous area. Ductus of accessory bursa emerges medioventrally, folded cuticle and small spines present to the left of its emerging area. Ductus seminalis inserted on ventral side.

\section{Molecular data (Table 1, Fig. 9)}

BIN URI: BOLD:ABA3262. The maximum intraspecific divergence of the barcode region is considerable with $1.59 \%(n=4)$, supporting two geographically separated clusters in the Dinaric Mts. and Rila Mts. The minimum distance to the nearest neighbour, P. apenninana sp. nov. is $3.69 \%$.

\section{Ecology}

The moths fly in July-August at daytime, in the morning and late afternoon until twilight, in sunny, calm weather. Preimaginal stages and larval host plant are unknown. Habitat: humid subalpine meadows at altitudes from 2000 to $2600 \mathrm{~m}$ a.s.l.

\section{Distribution (Fig. 10)}

Known from the highest Balkan mountain systems: Dinaric Mts, Rila Mts, Pirin Mts, and most probably Carpathian Mts (material not checked by us).
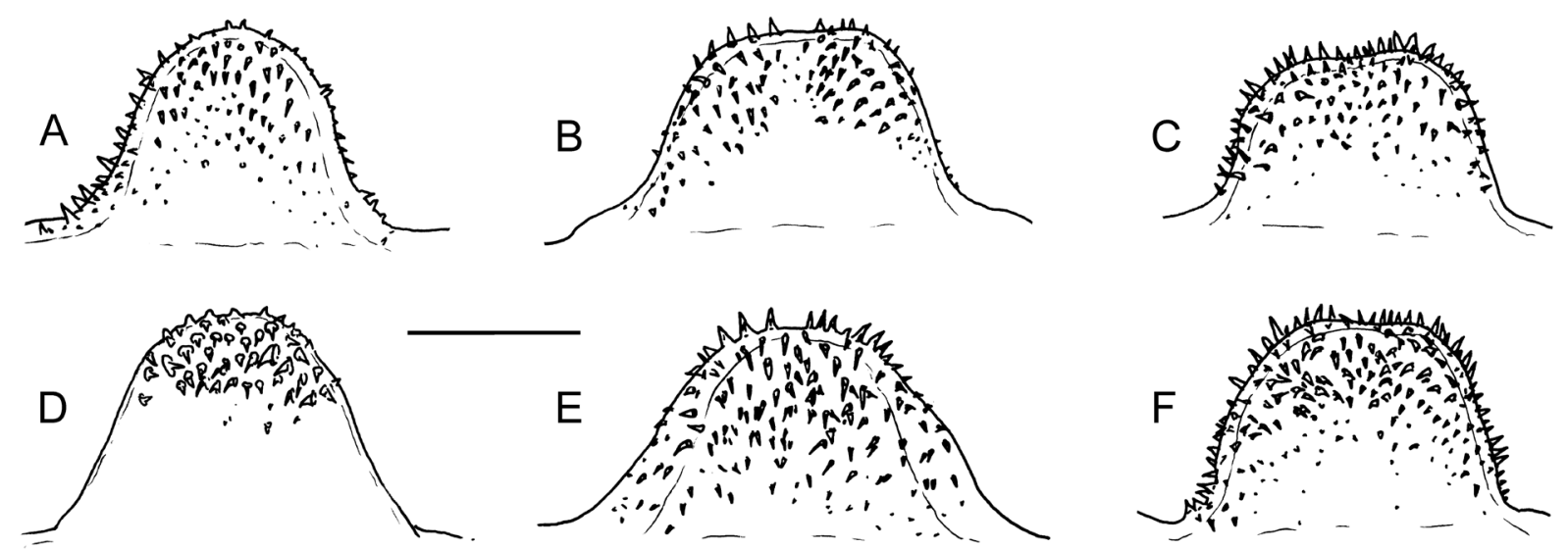

Fig. 3. Transtilla of Phtheochroa spp. A-B. P. schawerdae (Rebel, 1908) comb. nov., Bulgaria, Rila Mts. - C. P. alpinana sp. nov., France, Alpes Maritimes, holotype. - D. P. apenninana sp. nov., Italy, Gran Sasso National Park, holotype. - E. P. frigidana (Guenée, 1845) stat. rev., Andorra, Pyrenees, neotype of Eupoecilia frigidana. - F. P. cantabriana sp. nov., Spain, Picos de Europa National Park, paratype. Scale bar $=250 \mu \mathrm{m}$, all to scale. 
Table 1. Minimal uncorrected COI p-distances between different taxa of the $P$. frigidana s. lat. species complex.

\begin{tabular}{cccccc}
\hline & P. frigidana & P. cantabriana & P. alpinana & P. apenninana & P. schawerdae \\
\cline { 2 - 6 } P. frigidana & 0 & 3.69 & 6.11 & 5.43 & 4.92 \\
P. cantabriana & 3.69 & 0 & 5.94 & 5.6 & 4.43 \\
P. alpinana & 6.11 & 5.94 & 0 & 5.8 & 4.01 \\
P. apenninana & 5.43 & 5.6 & 5.8 & 0 & 3.69 \\
P. schawerdae & 4.92 & 4.43 & 4.01 & 3.69 & 0 \\
\hline
\end{tabular}

\author{
Phtheochroa alpinana sp. nov. \\ urn:lsid:zoobank.org:act:704B04D3-3AAA-4554-A4D4-0F7C9439173D \\ Figs 1E-F, 2C, 3C, 4D-E, 6A-B, 8B, 9, 10; Table 1
}

\title{
Diagnosis
}

The forewing upperside is paler than in $P$. schawerdae and P. apenninana sp. nov. and somewhat deeper yellow than in P. frigidana and P. cantabriana sp. nov. The hindwings are pale grey as in P. frigidana and $P$. cantabriana sp. nov. The vesica easily distinguishes this species from all other members of the group: with large dorsal and ventral diverticula; P. frigidana has only one diverticulum (dorsal); the diverticula on the other three species are oriented more or less laterally. The shape of the valva resembles those of $P$. frigidana. The phallic process is slightly curved to the right and resembles that of $P$. cantabriana $\mathrm{sp}$. nov. The female genitalia are generally similar to these of $P$. schawerdae, but the sclerotized area of the corpus bursae is larger, with three long folds on the right ventral side; the folds in $P$. schawerdae are short and more numerous (5-6).

\section{Etymology}

The specific name is a feminine adjective derived from the name of the Alps.

\section{Material examined}

\section{Holotype}

FRANCE: 0 , pinned, spread, well-preserved, three labels: // FRANKREICH Alpes Maritimes Tete Chaudon, 2200 m NE. Col de la Boira 20.7.1991 leg. Huemer \& Tarmann // Gen. prep. ô 1/20.7.1991 [genitalia slide number] // HOLOTYPE Phtheochroa alpinana Zlatkov \& Huemer, 2017 [red label] // (TLMF).

\section{Paratypes}

FRANCE : 1 , three labels: // FRANKREICH Alpes Maritimes Tete Chaudon, $2200 \mathrm{~m}$ NE. Col de la Boira 20.7.1991 leg. Huemer \& Tarmann // Gen. prep. đ 2/20.7.1991 [genitalia slide number] // PARATYPE Phtheochroa alpinana Zlatkov \& Huemer, 2017 [red label] // (TLMF); 1 o, with three labels: // locality data label as preceding // Gen. prep. o 3/20.7.1991 [genitalia slide number] // PARATYPE Phtheochroa alpinana Zlatkov \& Huemer, 2017 [red label] // (TLMF); 2 ふे, each with two labels: // FRANKREICH Dep. Alpes-Maritimes Marguareis W-Hang Navela, 2100-2200 m 21.23.7.1990 leg. Huemer \& Tarmann // PARATYPE Phtheochroa alpinana Zlatkov \& Huemer, 2017 [red label] // (TLMF); 1 q, with five labels: // France, Alpes Maritimes, $2000 \mathrm{~m} 6$ km NW Tende 
Mont Chajol 5.vii.2008 O. Karsholt // ZMUC 00400703 // Coll. ZMUC, Copenhagen Denmark [yellow label] // DK Copenhagen Zool. Museum + Genitalia slide No. 1/5.7.2008 // PARATYPE Phtheochroa alpinana Zlatkov \& Huemer, 2017 [red label] // (ZMUC); 1 , , five labels, all same as preceding but: // ZMUC 00400704 // DK Copenhagen Zool. Museum $\odot$ Genitalia slide No. 2/5.7.2008 // (ZMUC).

ITALY: 5 ठิึ, 1 q, each with two labels: // ITALIA Prov. Imperia Punta Marguareis S-Hang, 2250$2400 \mathrm{~m}$ 19.7.1991 leg. Huemer \& Tarmann // PARATYPE Phtheochroa alpinana Zlatkov \& Huemer, 2017 [red label] // (TLMF); 1 o, three labels: // ITALIA Prov. Imperia Punta Marguareis 2450-2600 m 23.7.1990 leg. Huemer \& Tarmann // TOR $105 \lesssim$ P. Huemer [genitalia slide number] // PARATYPE Phtheochroa alpinana Zlatkov \& Huemer, 2017 [red label] // (TLMF); 1 + , two labels: // ITALIA Prov. Imperia Punta Marguareis 2450-2600 m 23.7.1990 leg. Huemer \& Tarmann // PARATYPE Phtheochroa alpinana Zlatkov \& Huemer, 2017 [red label] // (TLMF).

\section{Description}

Male (Fig. 1E)

HEAD. Frons and vertex covered with creamy scales. Labial palps pointed anterad, long, dorsally creamy, laterally and ventrally brown. Antennae with scapus and pedicellus dorsally brown, ventrally white; flagellum with creamy scales.

Thorax. Dorsally creamy with brown scales in middle, ventrally creamy with brown scales. Tegula yellowish, with brown scales laterally. Forewing length 8.4-10.4 $\mathrm{mm}(\mathrm{x}=9.0, \mathrm{n}=9)$. Forewing long and narrow, with pointed apex, upperside ground colour yellow with paler distal half and inconspicuous

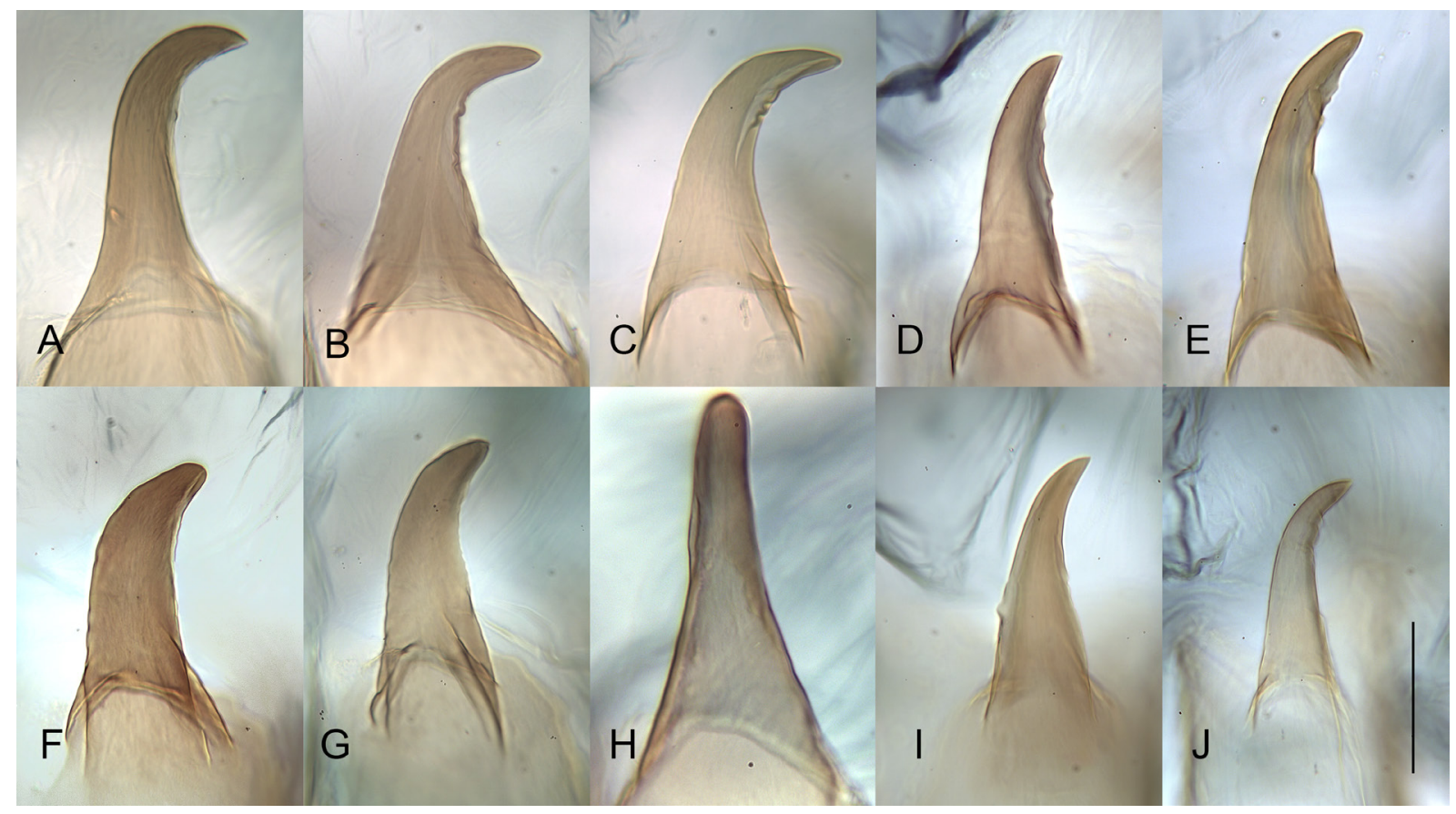

Fig. 4. Ventral phallic process of Phtheochroa spp., ventral view. A-C. P. schawerdae (Rebel, 1908) comb. nov. A-B. Bulgaria, Rila Mts. C. Republic of Macedonia, Korab Mts. -D-E. P. alpinana sp. nov., France, Alpes Maritimes. D. Holotype. E. Paratype. - F-G. P. apenninana sp. nov., Italy, Gran Sasso National Park. F. Paratype. G. Holotype. - H. P. frigidana (Guenée, 1845) stat. rev., Andorra, Pyrenees, neotype of Eupoecilia frigidana. - I-J. P. cantabriana sp. nov., Spain, Picos de Europa National Park. I. Holotype. J. Paratype. Scale bar $=100 \mu \mathrm{m}$, all to scale. 


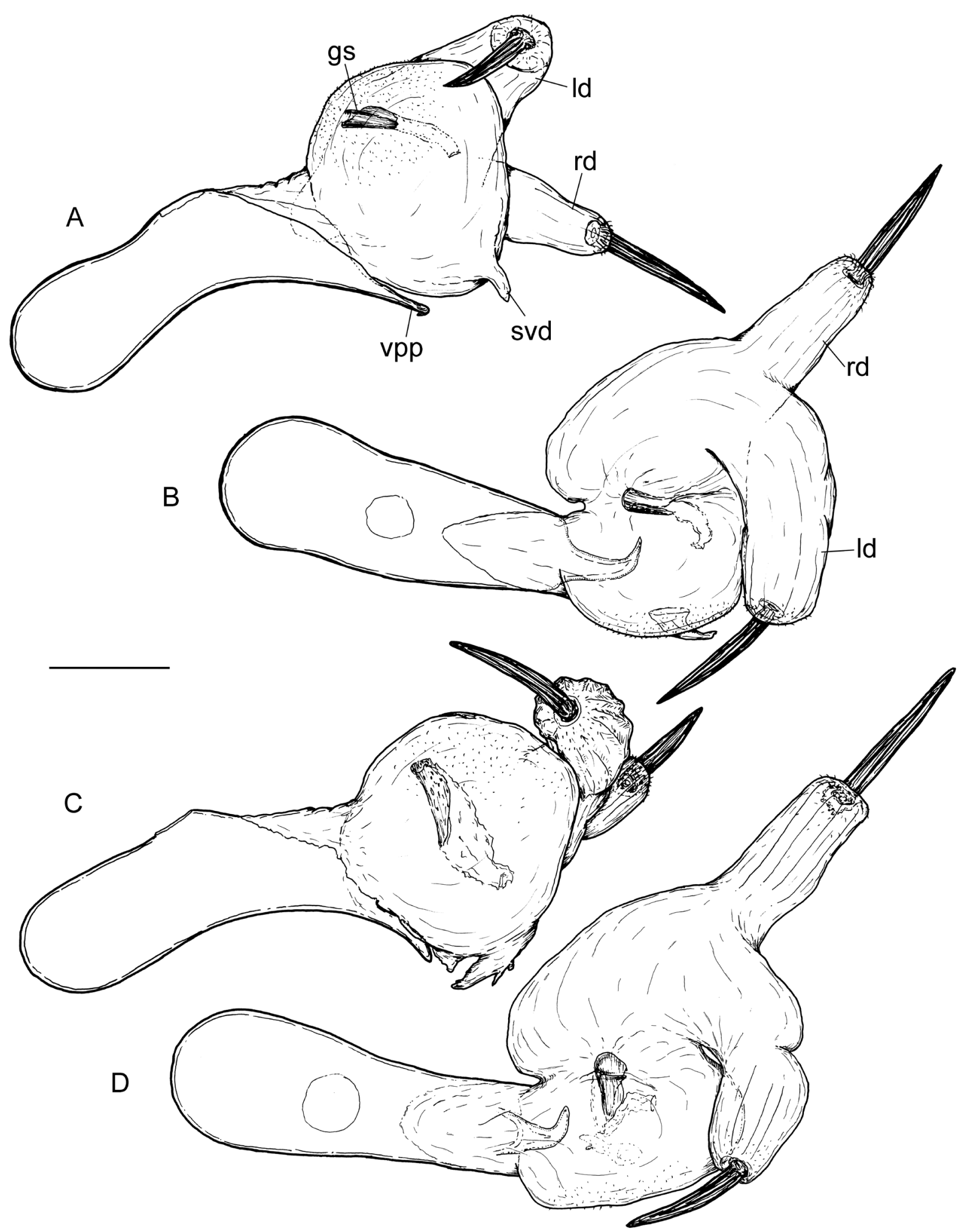

Fig. 5. Phalli with vesica everted, Phtheochroa schawerdae (Rebel, 1908) comb. nov. A-B. Bulgaria, Rila Mts. -C-D. Republic of Macedonia, Korab Mts. A, C: left. B, D: dorsal. Abbreviations: gs = gonopore sclerotization; $1 \mathrm{ld}=$ left diverticulum; $\mathrm{rd}=$ right diverticulum; $\mathrm{svd}=$ small ventral diverticulum; $\mathrm{vpp}=$ ventral phallic process. Scale bar $=250 \mu \mathrm{m}$. 
rust dorsal blotch, underside dark grey with scattered white scales in apical area, cilia pale yellow. Hindwings with upperside grey, underside grey with white costa and white longitudinal lines, cilia white with pale grey basal part.

AвDOMEn. Grey.

Genitalia (Fig. 2C). Curvature of valva prominent. Rest of valva, uncus and socii resembles those in P. schawerdae. Transtilla (Fig. 3C) wide, rectangular apically, with shallow median incision. Phallus (Fig. 6A-B) curved ventrally, with long, slender medioventral process (Fig. 4D-E), with apex slightly curved to the right. Vesica with subspherical proximal part and large part protruded from the right, bearing two large diverticula ending with cornuti. A furrow divides the two parts. Gonopore sunk in dorsal portion of furrow and surrounded by large sclerotized plate with uneven surface (distal part of ductus ejaculatorius). Right part of vesica protrudes in wider, conical, almost straight dorsal and narrower, cylindrical, curved ventral diverticulum. Cornuti aciculate and capitate, very robust, large, ventral one larger and slightly curved near apex. Proximal part of vesica bears a large conical ventral protrusion (diverticulum) with small processes. Acanthae present on posterior side of proximal part of vesica and at end of diverticula.

\section{Female (Fig. 1F)}

Considerably smaller than male. Head and thorax resemble those of male, but with forewing length 7.2-9.2 $\mathrm{mm}(\mathrm{x}=7.9, \mathrm{n}=5)$, upperside with rust brown dorsal blotch and subterminal fascia. Hindwing upperside grey, underside white with scattered grey scales. Abdomen grey. Female genitalia (Fig. 8B) with tergum 8 medially membranous, sterigma with two lateral protuberances, antrum nearly rectangular, with round anterior angles. Apophyses anteriores longer than apophyses posteriores. Ductus bursae ventrally membranous, with conical diverticulum of thick cuticle slightly curved to the left. Corpus bursae with large sclerite that starts on right side of ductus bursae with folds, then expands anteroventrally forming large ventral sclerotization and laterally to the left, then passes on dorsal side where it forms several folds on ductus bursae. Anterior medial part of corpus bursae with folded membranous area extending to the right. Ductus of accessory bursa emerges medioventrally, folded cuticle and small spines present to the left of its emerging area. Ductus seminalis inserted on ventral side.

Molecular data (Table 1, Fig. 9)

BIN URI: BOLD:AAL5381. The intraspecific divergence of the barcode region is unknown $(n=1)$. The minimum distance to the nearest neighbour, P. schawerdae from the Dinaric Mts is $4.01 \%$.

\section{Ecology}

Preimaginal stages and larval host plant are unknown. The type material was collected in July at altitudes of about $2200 \mathrm{~m}$ a.s.1. According to Bassi \& Scaramozzino (1989) the moths fly in two generations from April to July. However, material collected by these authors in the Italian Alps dates from mid- to late May and was collected at relatively low altitudes from 1200 to $1350 \mathrm{~m}$ a.s.l. From available data it thus seems more likely that the species is univoltine with a flight period from May to July, depending on climatic conditions and elevation. Habitat: the type material was collected in alpine grassland above the tree-line.

\section{Distribution (Fig. 10)}

So far known only from the south-western Alps (France, Italy). A record from the Slovenian Alps (as P. frigidana) (Lesar et al. 2009) is doubtful and may refer to P. schawerdae. 
Phtheochroa apenninana sp. nov. urn:1sid:zoobank.org:act:12684A15-E318-488F-9908-F8D8541C089C

Figs 1G, 2D, 3D, 4F-G, 6C-D, 9, 10; Table 1

\section{Diagnosis}

Externally, $P$. apenninana sp. nov. resembles $P$. schawerdae but the male genitalia are different. The vesica in $P$. apenninana sp. nov. has a larger right part than in P. schawerdae; the angle between the axes of the phallus and right diverticulum is smaller (maximum $90^{\circ}$ ) than in P. schawerdae $\left(100-120^{\circ}\right.$ ). The phallic process in P. apenninana sp. nov. is shorter, wider and not strongly curved; the opposite is the case in $P$. schawerdae. Both the wing colouration and male genitalia distinguish $P$. apenninana sp. nov. from $P$. alpinana sp. nov., $P$. frigidana and $P$. cantabriana sp. nov. The vesicae of $P$. apenninana sp. nov. and $P$. cantabriana sp. nov. are similar but the angle between the axes of phallus and right diverticulum in P. cantabriana is larger.

\section{Etymology}

The specific name is a feminine adjective derived from the name of the Apennines.

\section{Material examined}

\section{Holotype}

ITALY: ${ }^{\lambda}$, pinned, with partially spread wings, slightly worn, four labels: // Italia, Prov. L'Aquila NP Gran Sasso ex Miniera di Lignite $13^{\circ} 42,8^{\prime}$ E, 42 ${ }^{\circ} 25,6^{\prime}$ N 1750 m, 14-15.7.2010 leg. Huemer TLMF 2010-020 // BC TLMF Lep 01572 [green label] // Gen. prep. đ̊ 1/14-15.7.2010 [genitalia slide number] // HOLOTYPE Phtheochroa apenninana Zlatkov \& Huemer, 2017 [red label] // (TLMF).

\section{Paratype}

ITALY: 1 Oे, pinned, with partially spread wings, slightly worn, four labels: // Italia, Prov. L'Aquila NP Gran Sasso, Campo Imperatore, E Observatorio 1334,4' E, 42²6,9' N 2010 m, 13.7.2010 leg. Huemer TLMF 2010-020 // BC TLMF Lep 03037 [green label] // Gen. prep. ô 1/13.7.2010 [genitalia slide number] // PARATYPE Phtheochroa apenninana Zlatkov \& Huemer, 2017 [red label] // (TLMF).

\section{Description}

Male (Fig. 1G)

HEAD. Frons devoid of scales (worn specimens), vertex yellow brown, labial palps creamy. Antennae with scapus and pedicellus brown dorsally and creamy ventrally, flagellum with creamy scales.

Thorax. Dorsally, including tegulae, with yellow and brown scales, ventrally whitish, fore- and middle legs brown, hindlegs white. Forewing length 7.2-7.4 $\mathrm{mm}(\mathrm{n}=2)$, upperside deep yellow, with remnants of rust dorsal blotch, cilia concolorous with upperside, underside dark grey, with white scales in costal area. Hindwing upper- and underside dark grey, with white costal area and white longitudinal line between veins $M_{1}$ and $M_{2}$ starting from discal cell and ending in cilia.

ABdomen. Grey.

Genitalia (Fig. 2D). Valva with weak curvature, appears slender but this may be due to preparation. Rest of valva, uncus and socii very similar to those of P. schawerdae. Transtilla (Fig. 3D) large, round. Phallus (Fig. 6C-D) slightly curved ventrally, with wide and blunt medioventral process (Fig. 4F-G), with apex curved to the right. Vesica in general resembles that of $P$. schawerdae, with large main part protruded at right from sclerotized phallus and two large diverticula bearing long, robust cornuti. Small, conical undulating structure (diverticulum) emerges ventrally from main part. Gonopore located dorsally, 


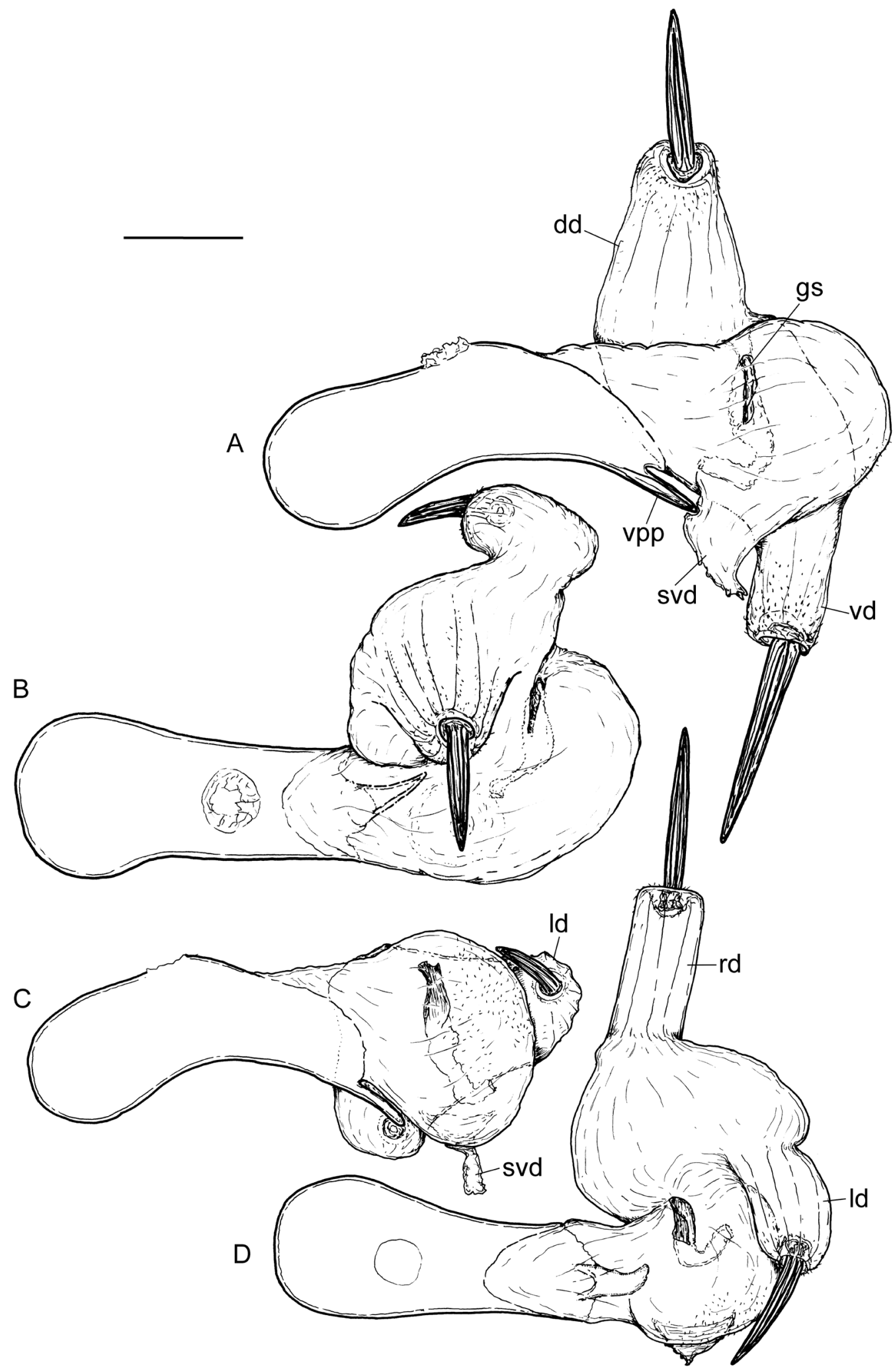

Fig. 6. Phalli with vesica everted of Phtheochroa spp. A-B. P. alpinana sp. nov., France, Alpes Maritimes, holotype. - C-D. P. apenninana sp. nov., Italy, Gran Sasso National Park, holotype. A, C: left. B, D: dorsal. Abbreviations: $\mathrm{dd}=$ dorsal diverticulum; $\mathrm{vd}=$ ventral diverticulum; other abbreviations as in Fig. 5. Scale bar $=250 \mu \mathrm{m}$. 
surrounded by semicylindrical sclerotized plate with minute, lentiform tubercles. Main part medially constricted by circular furrow in which gonopore is sunk. Portion located distally of furrow very large, heart-shaped in dorsal view. Main part of vesica looks ovoid in lateral left view. Diverticula emerge from right portion in opposing directions, right one straight, emerging from ventral half of right part and directed laterally, left one curved and also pointed laterally. Length and orientation of diverticula relatively constant. Axes of right diverticulum and sclerotized phallus form an angle of maximum $90^{\circ}$. Cornuti aciculate, capitate, of equal length, left one slightly bent. Barely discernible acanthae present on left portion of main part of vesica and at end of diverticula.

\section{Female}

Unknown.

Molecular data (Table 1, Fig. 9)

BIN URI: BOLD:ACA9597. The maximum intraspecific divergence of the barcode region is $0 \%(\mathrm{n}=2)$. The minimum distance to the nearest neighbour, P. schawerdae from the Dinaric Mts is 3.69\%.

\section{Ecology}

Preimaginal stages and larval host plant are unknown. The moths fly in July. Habitat: the type material was collected in alpine grassland above the treeline.

Distribution (Fig. 10)

Apennine Mountains.

Phtheochroa frigidana (Guenée, 1845) stat. rev.

Figs $1 \mathrm{H}, 2 \mathrm{E}, 3 \mathrm{E}, 4 \mathrm{H}, 7 \mathrm{~A}-\mathrm{B}, 9$, 10; Table 1

Eupoecilia frigidana Guenée, 1845a: 298.

Cochylis flavidana Guenée, 1845b: 66.

Aphelia sulphurana Guenée, 1845b: 67.

Conchylis andorrana Millière, 1865: 167, pl. 69, figs 4-5.

Hysterosia frigidana - Razowski 1970: 73, pl. 29, fig. 3, pl. 112, fig. 3.

Phtheochroa frigidana - Razowski 1991a: 103.

non Aphelia sulphurosana - Razowski 1970: 73.

\section{Diagnosis}

Externally, this species is practically indistinguishable from $P$. cantabriana sp. nov. The characters of the phallus and vesica easily separate this species from all other members of the group: the phallic process is straight, in contrast to the other species with a curved process; the vesica has a single long dorsal diverticulum, the other species have two diverticula. The paler fore- and hindwing upperside colour distinguishes $P$. frigidana from $P$. schawerdae and $P$. apenninana sp. nov., both with deep yellow forewings and dark grey hindwings.

\section{Material examined}

\section{Neotype}

ANDORRA: 3 , pinned, with partially spread wings, slightly worn, four labels: // ANDORRA Port de Cabús, 2290 m 1²5'13" E, 42³2'45" N 16.vii.2012 leg. Huemer TLMF 2012-011 // BC TLMF Lep 

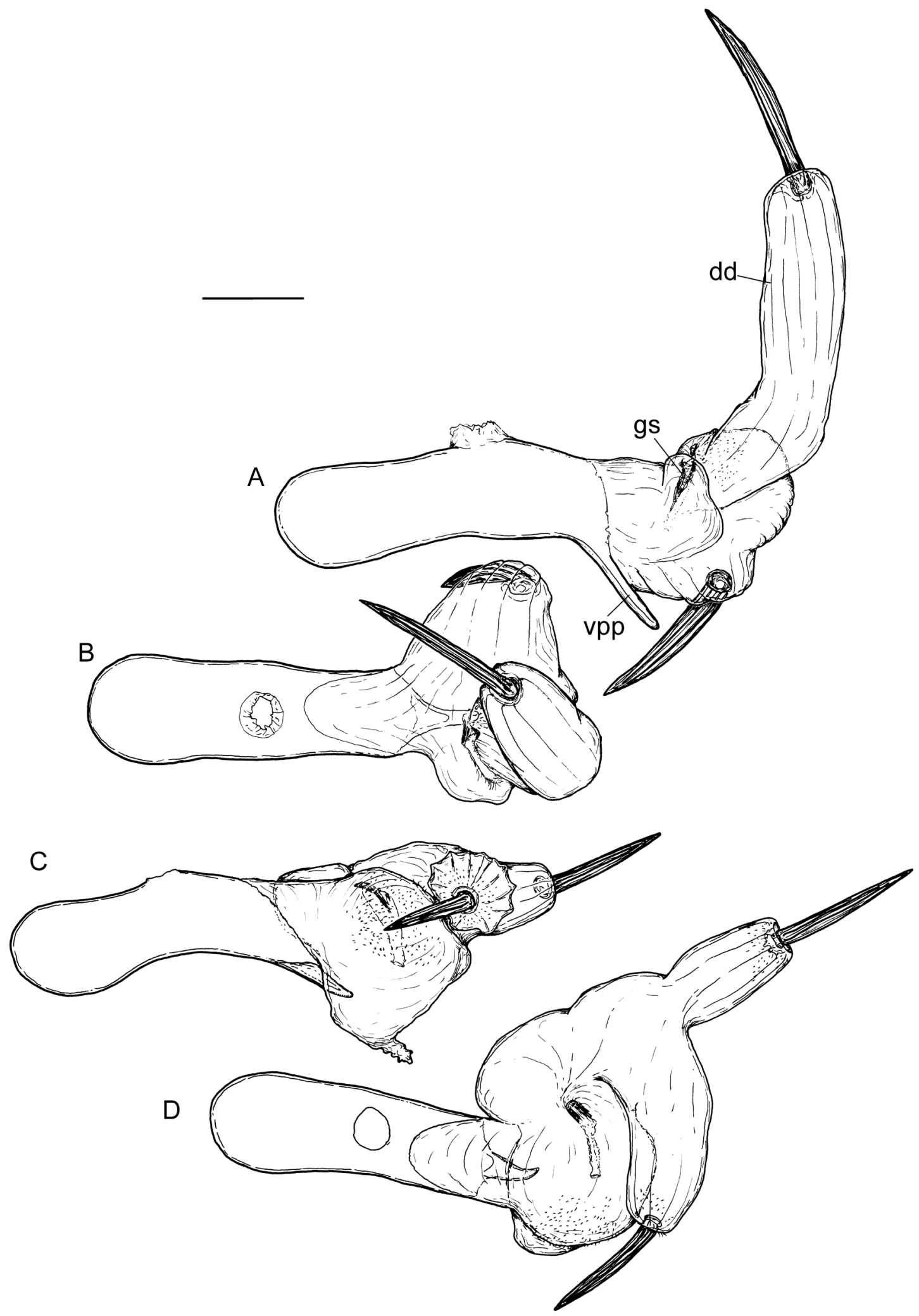

Fig. 7. Phalli with vesica everted of Phtheochroa spp. A-B. P. frigidana (Guenée, 1845) stat. rev., Andorra, Pyrenees, neotype of Eupoecilia frigidana. - C-D. P. cantabriana sp. nov., Spain, Picos de Europa National Park, holotype. A, C: left. B, D: dorsal. Abbreviations as in Figs 5-6. Scale bar = $250 \mu \mathrm{m}$. 
08349” [green label] // Gen. prep. § 1/16.7.2012 [genitalia slide number] // NEOTYPE Eupoecilia frigidana Guenée, 1845 Zlatkov \& Huemer, 2017 des. [red label] // (TLMF).

\section{Other material}

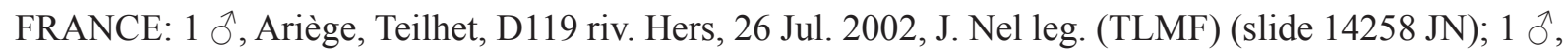
Pyrénées Orientales, Formiguères, le Galbe, 1700 m a.s.1., 3 Aug. 1993, J. Nel leg. (TLMF) (slide 01646 JN); 1 đૈ, Pyrénées Orientales, Col de Puymorens, 1950 m a.s.l., 30 Jun. 2003, J. Junnilainen leg. (JJ).

\section{Redescription}

\section{Male (Fig. 1H)}

HEAD. Most scales from frons and vertex missing, remaining white. Labial palps long, pointed anterad, with white scales dorsally and ochreous laterally. Antennae filiform, with creamy scales.

THORAx. Dorsally covered with white scales, ventrally with whitish scales. Tegula whitish, laterally with ochreous scales. Forewing length $8.8-10.2 \mathrm{~mm}(\mathrm{x}=9.6, \mathrm{n}=4)$. Forewing long, narrow, with pointed apex, upperside ground colour creamy, more intense yellowish at base and along proximal half of costa; no pattern recognizable in studied specimens, but a specimen figured in Millière (1865) has rust dorsal blotch and subterminal fascia. Underside dark grey, with scattered white scales, especially in apical area. Cilia whitish, with darker basal line. Hindwing upperside pale grey, underside white, with scattered grey scales. Cilia white.

Abdomen. Grey.

Genitalia (Fig. 2E). Curvature of valva prominent. Rest of valva, uncus and socii resembles those of P. schawerdae. Transtilla of neotype (Fig. 3E) short and wide at base, narrow and round apically, but in other specimens with angular apical part. Phallus (Fig. 7A-B) almost straight, with very large, straight, slender, blunt medioventral process (Fig. 4H). Vesica with ovoid part protruded to the right bearing anteroventrally directed cornutus. Long, slender, bent at basal third, anterodorsally directed diverticulum with cornutus emerges from the left dorsal part of vesica. Gonopore located dorsally, at base of diverticulum, with sclerotized plate and collar-like fold expanding laterally. Cornuti unequal, ventral one shorter, thicker and curved, dorsal one long, slender, sharp-tipped and only slightly curved. Acanthae present in small area on dorsal part, near gonopore, and scarcely around attachment areas of cornuti.

\section{Female}

A drawing by Razowski (1970: pl. 112, fig. 3) may represent the female genitalia of a specimen of this species from the Pyrenees.

Molecular data (Table 1, Fig. 9)

BIN URI: BOLD:ACA9598. The intraspecific divergence of the barcode region is unknown $(n=1)$. The minimum distance to the nearest neighbour, P. cantabriana sp. nov. is $3.69 \%$.

\section{Ecology}

Preimaginal stages and larval host plant are unknown. According to the label data, the moths fly from the middle of July to the beginning of August. Guenée (1846) reported May and June. The habitat of the neotype was alpine meadows above the tree-line, but based on supplementary material this species also occurs at lower altitudes. 


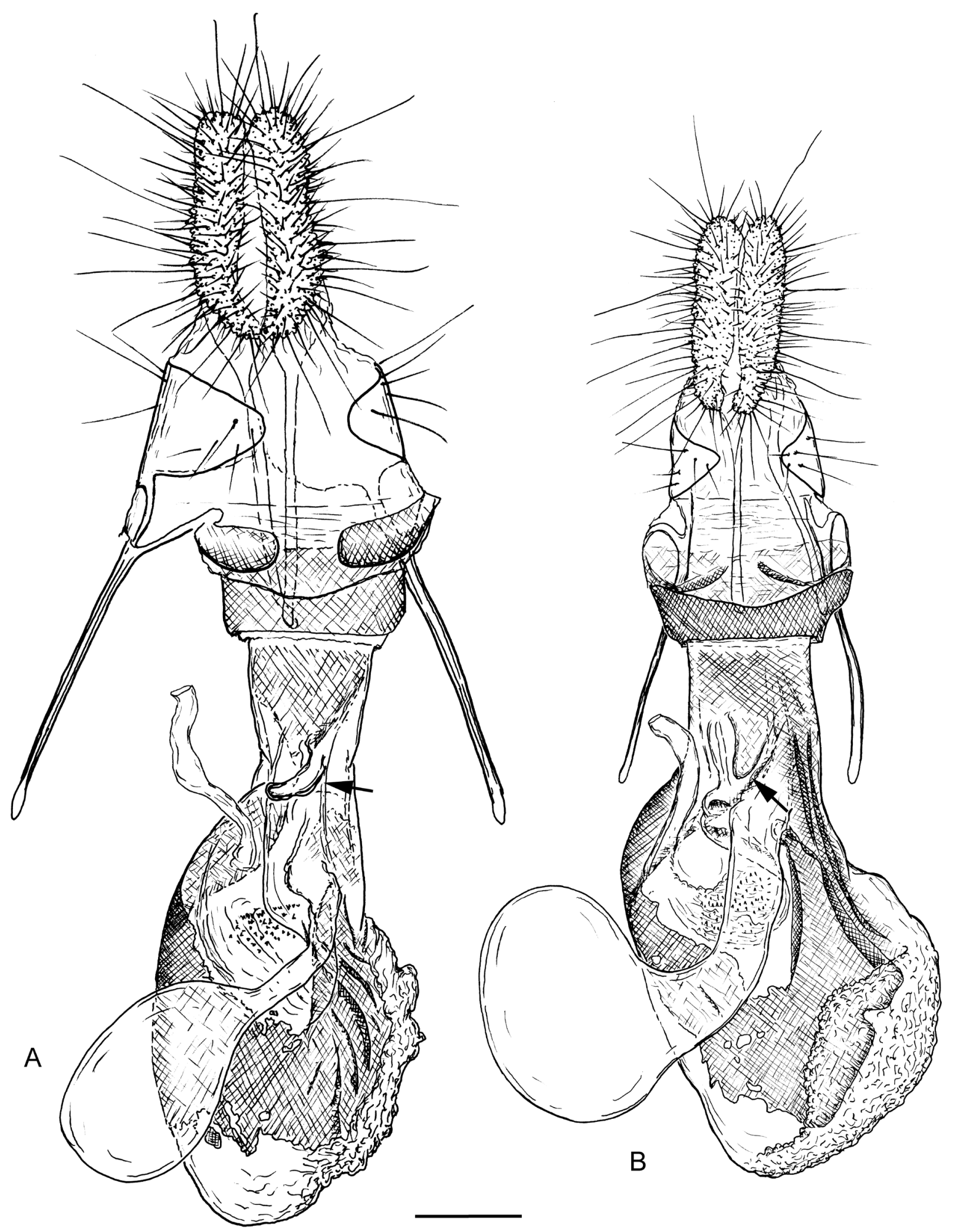

Fig. 8. Female genitalia of Phtheochroa spp. A. P. schawerdae (Rebel, 1908) comb. nov., Bulgaria, Rila Mts. - B. P. alpinana sp. nov., France, Alpes Maritimes, paratype. Arrow: ventral diverticulum of ductus bursae. Scale bar $=250 \mu \mathrm{m}$. 


\title{
Distribution (Fig. 10)
}

Pyrenees. All previous records from other mountains need revision.

\section{Remarks}

The erroneous type locality of "Dalecarlia" in the original description of $P$. frigidana is a major hindrance in the interpretation of this taxon. Therefore, in order to maintain the stability of the nomenclature, we have designated a neotype for Eupoecilia frigidana in accordance with past usage of this name for populations from the Pyrenees (Razowski 1970), with Cochylis flavidana and C. andorrana as junior synonyms (Razowski 2002).

\author{
Phtheochroa cantabriana sp. nov. \\ urn:1sid:zoobank.org:act:AB5396E9-E6BF-487D-8CC3-D5E7F2B1674E \\ Figs 1I-J, 2F, 3F, 7C-D, 9, 10; Table 1
}

\section{Diagnosis}

Externally, this species is practically indistinguishable from P. frigidana; the same is valid for most of the genital characters, but the vesica is strikingly different. The general shape of the vesica resembles that of $P$. schawerdae and P. apenninana sp. nov. but in lateral left view its main part looks angular (not ovoid), and the angle between the axes of the phallus and right diverticulum (in dorsal view) is usually larger (more than $130^{\circ}$ ). The wing upperside colouration of $P$. cantabriana sp. nov. is much paler than that of $P$. schawerdae and $P$. apenninana sp. nov.

\section{Etymology}

The specific name is a feminine adjective derived from the name of the Cantabrian Mountains.

\section{Material examined}

\section{Holotype}

SPAIN: $\widehat{\partial}$, pinned, with partially spread wings, slightly worn, four labels: // ESPANA, Prov. Cantabria PN Picos de Europa Espinama, Portillas de Poqueion, 1340 m 446,53' W, 43ํ0, $92^{\prime}$ N 11.7.2012, leg. Huemer TLMF 2012-011 // BC TLMF Lep 08335 [green label] // Gen. prep. § 1/11.7.2012 [genitalia slide number] // HOLOTYPE Phtheochroa cantabriana Zlatkov \& Huemer, 2017 [red label] // (TLMF).

\section{Paratypes}

SPAIN: 1 , pinned, with partially spread wings, slightly worn, four labels: // ESPANA, Prov. Cantabria PN Picos de Europa Espinama, Portillas de Poqueion, $1340 \mathrm{~m} 4^{\circ} 46,53^{\prime} \mathrm{W}, 43^{\circ} 08,92^{\prime} \mathrm{N}$ 11.7.2012, leg. Huemer TLMF 2012-011 // BC TLMF Lep 08336 [green label] // Gen. prep. $\widehat{0}$ 2/11.7.2012 [genitalia slide number] // PARATYPE Phtheochroa cantabriana Zlatkov \& Huemer, 2017 [red label] // (TLMF); 1 ô, pinned, with partially spread wings, slightly worn, three labels: // locality data label as preceding // BC TLMF Lep 08334 [green label] // Gen. prep. $\widehat{0}$ 3/11.7.2012 [genitalia slide number] // PARATYPE Phtheochroa cantabriana Zlatkov \& Huemer, 2017 [red label] // (TLMF); 1 ô, well-preserved, with spread wings, five labels: // Spain, Cantabria Puerto San Glorio Picos [de] Europa, 1610 m 10.vi.1988 P. Stadel Nielsen [hand written] // ZMUC Tortricidae Spanish Revision specimen \# 1341 [green label] // Coll. ZMUC, Copenhagen Denmark [yellow label] // DK Copenhagen Zool. Museum $\widehat{\sigma}$ Genitalia slide No. 1/10.6.1988 // PARATYPE Phtheochroa cantabriana Zlatkov \& Huemer, 2017 [red label] // (ZMUC). 


\section{Description}

Male (Fig. 1I-J)

HEAD. Frons beige, vertex creamy, labial palps long, pointed anterad, white dorsally, rust laterally and brown ventrally. Antennae with scapus and pedicellus dorsally rust, ventrally white, flagellum with white scales.

THORAX. Dorsally with white and grey scales, tegula the same but laterally rust, ventrally whitish, foreand middle legs brownish, hind legs whitish. Forewing long and narrow with pointed apex, length 8.8-10.4 $\mathrm{mm}(\mathrm{x}=9.6 \mathrm{~mm}, \mathrm{n}=4)$, upperside pale yellow with rust base, sometimes with rust dorsal blotch and subterminal fascia, cilia white, underside pale grey, with white scales in costal and anal areas. Hindwing upperside pale grey, cilia white with pale grey basal part, underside white with pale grey scales along veins $\mathrm{R}$ and $\mathrm{M}$.

ABdomen. Grey.

Genitalia (Fig. 2F). Curvature of valva weak, rest of valva, uncus and socii very similar to those of P. schawerdae. Transtilla (Fig. 3F) large, rectangular. Phallus (Fig. 7C-D) curved ventrally, medioventral process slender, pointed, with apex slightly curved to the right. Vesica in general resembles that of $P$. schawerdae, with large main part protruded at right from sclerotized phallus and two large diverticula bearing long, robust cornuti. Small, conical undulating structure (diverticulum) emerges ventrally from main part. Gonopore located dorsally, surrounded by semicylindrical sclerotized plate with minute tubercles. Main part medially constricted by circular furrow, in which gonopore is sunk. Main part of vesica looks angular in lateral left view. Diverticula emerge close to each other from right side, right one straight, emerging from dorsal half of right part and pointed posterolaterally, left one curved and oriented laterally. In dorsal view, axes of right diverticulum and sclerotized phallus usually form angle of $120-140^{\circ}$. Cornuti aciculate, capitate, of equal length, left one slightly bent. Barely discernible acanthae present on left portion of main part of vesica and at end of diverticula.

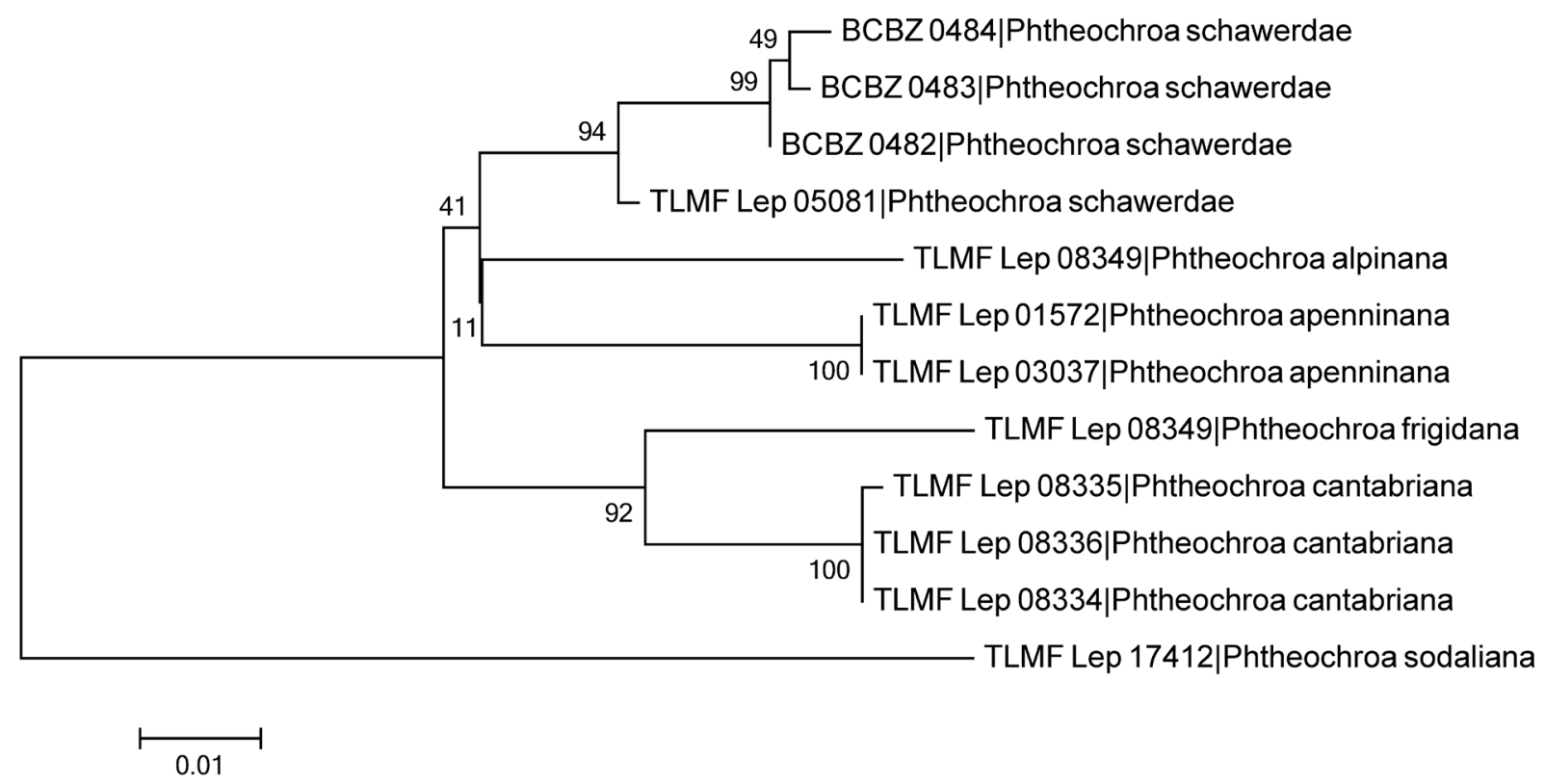

Fig. 9. Maximum likelihood tree (built with MEGA6) of cytochrome $c$ oxidase subunit I (COI) barcode fragments. Values at the nodes are bootstrap support values based on 500 replicates. 


\section{Female}

Unknown.

\section{Molecular data (Table 1, Fig. 9)}

BIN URI: BOLD:ACA9597. The maximum intraspecific divergence of the barcode region is $0.31 \%$ $(\mathrm{n}=3)$. The minimum distance to the nearest neighbour, P. frigidana, is 3.69\%.

\section{Ecology}

Preimaginal stages and larval host plant are unknown. The moths fly in June-July. Habitat: the type material was collected in montane meadows.

\section{Distribution (Fig. 10)}

Cantabrian Mountains.

\section{Discussion}

Eupoecilia frigidana was the first taxon described from this group (Guenée 1845a). The origin of the type material is uncertain; according to the original description the type locality is "Dalecarl.[ia]", which is a region in Sweden, but this taxon has never been reported outside southern Europe. Most probably, the type material originates from the Pyrenees (Razowski 1970) and we follow this interpretation in our selection of a neotype (see above). Guenée (1845b) described two further species from the Pyrenees, belonging to this group, Cochylis flavidana and Aphelia sulphurana, which were subsequently synonymized with $P$. frigidana (Ragonot 1894). Conchylis andorrana Millière, 1865, another synonym of $P$. frigidana, also originates from the Pyrenees (Ariège Mts). The type specimens of all these taxa are most likely lost (Gilligan et al. 2014), leaving only speculation as to their real taxonomical assignment.

The other available names from this species group originate from material collected on the Balkan Peninsula. Conchylis schawerdae Rebel, 1908 was described from the Dinaric Mts in Bosnia and later synonymized with $P$. frigidana (Razowski 1970), an action based, presumably, on the original description, since the type specimens of $C$. schawerdae are lost. Euxanthis drenowskyi Rebel, 1916 was described after material from the Rila Mts in Bulgaria and is considered as valid species in recent literature. It is the only species from the group with preserved type specimens.

In summary, two valid names exist in the present-day literature for taxa of the Phtheochroa frigidana species group: P. frigidana and P. drenowskyi. However, our molecular and morphological comparison of specimens from all main southern European mountain ranges revealed much greater diversity than previously recognized. Five geographically separated putative species can be recognized from the Cantabrian Mts, Pyrenees, SW Alps, Apennines and the Balkans (Fig. 10). These allopatric species are supported by subtle morphological characters of diagnostic value and considerable divergence of barcode sequences. It should be emphasized that the main morphological differences concern the threedimensional structure of the vesica, a character never studied before in this group. Some differences can be detected in the phallic process (Fig. 4), but in general, the rest of the male genitalia do not provide reliable diagnostic characters in this group (Figs 2-3). The shape of the uncus, socii, transtilla and valvae are commonly used characters in the taxonomy of Phtheochroa, but there is considerable intraspecific variation and these features are not of great significance in this particular group. Overreliance on these structures has been misleading taxonomists for a long time, producing unnecessary synonymy or omitting well-defined taxa.

The shapes of the vesicae and phalli in P. schawerdae, P. apenninana sp. nov. and P. cantabriana sp. nov. demonstrate considerable similarity; the most obvious difference between them is the angle formed by 
the axes of the phallus and right diverticulum (Figs 5-7). This is due not only to the mutual orientation of these structures, but also to the different development of other parts, which can be recognized only after careful morphological examination. It is interesting to note that the most isolated taxa, $P$. schawerdae and $P$. cantabriana sp. nov., differ in relatively few characters. At the same time, the differences in vesicae in $P$. apenninana sp. nov. and $P$. schawerdae are more prominent despite their smaller genetic and geographic distances. The phallus and vesica of $P$. frigidana are strikingly different from those of all other species in the group. Genetically, the nearest species to $P$. frigidana is $P$. cantabriana sp. nov., which in no way is supported by the genital morphology. It is interesting to note that the vesicae of $P$. schawerdae, $P$. apenninana sp. nov. and $P$. cantabriana sp. nov. are more similar to those of species belonging to a relatively distant group of Phtheochroa, P. procerana (Lederer, 1863) and P. unionana (Kennel, 1900), than to those of the other two species in the frigidana group, P. frigidana and P. alpinana sp. nov. (Zlatkov \& Huemer 2016). These facts support the assumption that the male genitalia, especially the "internal" (phallus and vesica) ones, in many cases diverge very rapidly and cannot provide a reliable phylogenetic signal. An intriguing structure presented in all the above-cited species of Phtheochroa, with the exception of $P$. frigidana, is a small conical ventral diverticulum of the vesica devoid of cornuti and acanthae. It is intensively stained by Chlorazol Black, has an uneven surface, sometimes small processes and folds, and is variably shaped among members of the same species, in contrast to the other large diverticula which have a relatively constant shape. Its function is entirely unknown, but one can speculate that it is an internal, non-eversible (in the living moth) structure, probably an apodeme for intrinsic phallic muscles rather than a real diverticulum.

The female genitalia of only two species of the group are known to us: P. schawerdae and P. alpinana sp. nov. (Fig. 8); those of probable P. frigidana were figured by Razowski (1970). The illustrations available from the literature do not correctly represent all characters. An important character not presented in the existing drawings is the presence of a ventral diverticulum of thick, colourless cuticle of the ductus bursae with its tip curved to the left, most probably serving to accommodate the ventral phallic process of the male. In general, the female genitalia of both studied species demonstrate considerable similarity, although some differences can be noticed in the shape of sclerotizations of the ductus and corpus bursae.

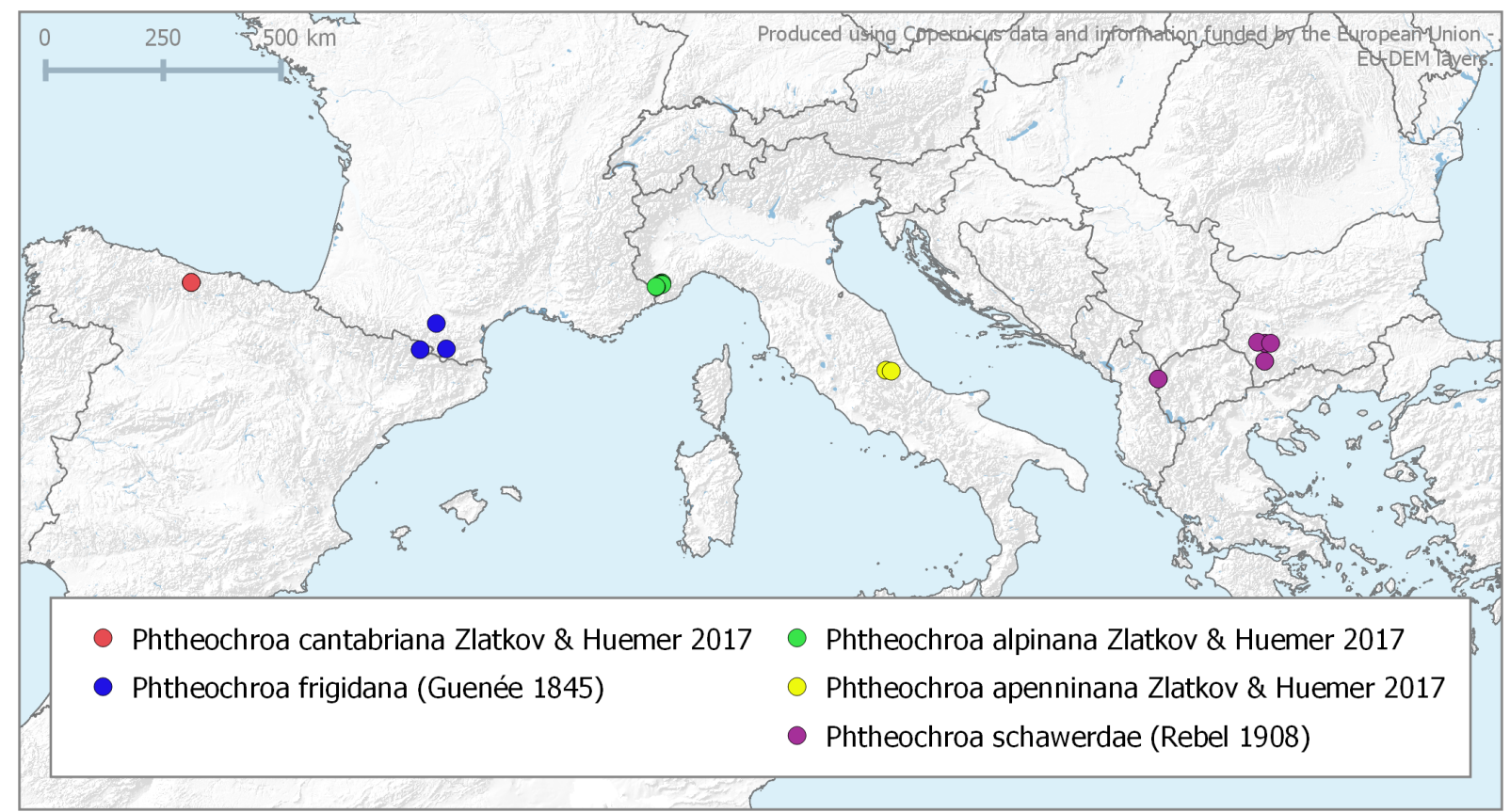

Fig. 10. Distribution of the Phtheochroa frigidana s. lat. species complex based on examined material. 
Comparison of the vesicae demonstrates that those of the Pyrenean specimens (Fig. 7A-B) are strikingly different from all other studied specimens. We consider the Pyrenean population as the true P. frigidana, because the original description was likely based on specimens from the Pyrenees (Razowski 1970). Also in this regard, the earlier synonymy of $P$. flavidana, $P$. andorrana and $P$. sulphurana with $P$. frigidana seems justified. The male genitalia of this species were probably illustrated by Razowski (1970: pl. 29, fig. 3). The structure of the vesica is not visible from these drawings, but the shapes of the transtilla and phallus do fit specimens from the Pyrenees studied by us. The vesica of the Alpine specimens is considerably different from those of the Pyrenean specimens and also differs from that of specimens collected in the other mountain massifs; therefore, we consider the southern Alpine population as a separate, undescribed taxon, a decision which is supported by considerable divergence of the barcode. Additionally, the genitalia of a female from the same locality in the Alps was compared with the drawing of "frigidana" genitalia of a specimen from the Pyrenees (Razowski 1970); differences in several characters can easily be noticed, which supports the contention that the Pyrenean and Alpine populations are separate species. The Cantabrian, Apenninian and Balkan populations demonstrate a similar structure of the vesicae, but can easily be separated by some details in the position of the diverticula and shape of the phallic process. The Cantabrian and Apenninian populations appear to be undescribed taxa. Two nominal taxa are known from the Balkans: P. schawerdae and P. drenowskyi. A specimen originating from the Dinaric system (Korab Mts, Macedonia) and presumably representing P. schawerdae (described fromVucija Bara, Bosnia) was examined. However, a morphological comparison with specimens of $P$. drenowskyi from the Rila Mts (Bulgaria) did not provide any reliable differences between these two taxa; thus, they appear conspecific, despite a considerable intraspecific barcode divergence. In the absence of specific morphological characters, $P$. drenowskyi should be treated as a junior synonym of $P$. schawerdae. The distribution range of $P$. schawerdae probably covers all higher Balkan mountains (above $2000 \mathrm{~m}$ ); it is reported and illustrated also from the Carpathian Mountains in Romania (Kovács \& Kovács 2004). The figures of male and female genitalia in this paper fit specimens from the Rila Mts, but the comparison is not conclusive, because the vesica is not everted.

These diagnostic morphological characters are supported by distinct barcode gaps for all putative taxa and are concordant to unique BINs (Barcode Index Number) in BOLD (Ratnasingham \& Hebert 2013). The intraspecific divergence is low, as far as is known from the relatively few samples, with the single exception being the allopatric populations of $P$. schawerdae in the Dinaric and Rila Mts. Conversely, the interspecific divergence varies from $3.69 \%$ to $6.11 \%$ (Table 1, Fig. 9). Similar or even lower values have been supportive for the delimitation of cryptic species of Lepidoptera in various groups (e.g., Pazhenkova et al. 2015).

Species delimitation of allopatric taxa is a critical task, as the biological species concept applying reproductive incompatibility cannot be proved under natural conditions. In such species the phylogenetic concept (Cracraft 1989) may be adopted and species concepts are rather based on diagnosability. To avoid artificial oversplitting, Mutanen et al. (2012) suggested species status for allopatric populations with a divergence in two or more independent characters. We follow this compromise and reserve species status for five allopatric populations, supported by both morphological characters and DNA barcode divergence.

The evolution of several alpine species is likely to be explained by climatic changes during the Pleistocene (Varga \& Schmitt 2008). Cyclic changes in temperature caused up- and down-range shifts and the disruption of formerly connected populations. The timing of alleged speciation processes is unknown, though molecular clock estimations of the COI gene suggest average substitution rates of 1.0 to $2.3 \%$ sequence divergence per million years in Lepidoptera (Kandul et al. 2004). However, the range of interspecific barcode variation in P. frigidana s. lat. with a minimum $3.69 \%$, at least indicates that 
gene flow was already interrupted by the early pleistocenic glaciation periods, commencing about 2.58 Mya.

\section{Acknowledgements}

We are most grateful to the team of Paul Hebert at the Canadian Centre for DNA Barcoding (Guelph, Ontario, Canada), whose sequencing work was enabled by funding from the Government of Canada to Genome Canada through the Ontario Genomics Institute. We also thank the Ontario Ministry of Research and Innovation and the Natural Sciences and Engineering Research Council of Canada (NSERC) for their support of the BOLD informatics platform. PH gratefully acknowledges the national park (NP) authorities of NP Mavrovo (Macedonia), NP Gran Sasso (Italy) and NP Picos de Europa (Spain) for the necessary collecting permits. Ole Karsholt (Natural History Museum of Denmark, Copenhagen) and Jari Junnilainen (Vantaa, Finland) provided important additional material. PH is furthermore indebted to the Promotion of Educational Policies, University and Research Department of the Autonomous Province of Bolzano-South Tyrol for helping to fund the project "Genetische Artabgrenzung ausgewählter arktoalpiner und boreomontaner Tiere Südtirols". Colin W. Plant (Bishops Stortford, UK) improved the paper linguistically, for which we express our gratitude. We would also like to thank the reviewers for their helpful and constructive comments. Finally, we are grateful for technical help from Hannes Kühtreiber and Benjamin Wiesmair (Innsbruck, Austria).

\section{References}

Anzaldo S.S., Dombroskie J., Brown J.W. 2014. Morphological variation, taxonomic distribution, and phylogenetic significance of cornuti in Tortricinae (Lepidoptera: Tortricidae). Proceedings of the Entomological Society of Washington 116 (1): 1-31. https://doi.org/10.4289/0013-8797.116.1.1

Bassi G. \& Scaramozzino P.L. 1989. Contributo allo studio della microlepidotterofauna Piemontese. 1. Note sul alcuni interessante perperti di Tortricidae (Lepidoptera). Rivista Piemontese di Storia naturale 10: $155-163$.

Cracraft J. 1989. Speciation and its ontology. The empirical consequences of alternative species concepts for understanding patterns and processes of differentiation. In: Otte D. \& Endler J.A. (eds) Speciation and its Consequences. Sinauer Associates, Sunderland, MA, USA.

de Waard J.R., Ivanova N.V., Hajibabaei M. \& Hebert P.D.N. 2008. Assembling DNA barcodes: analytical protocols. In: Cristofre M. (ed.) Methods in Molecular Biology: 275-293. Environmental Genetics. Humana Press Inc., Totowa, NJ, USA.

Gilligan T.M., Baixeras J., Brown J.W. \& Tuck K.R. 2014. T@RTS: Online World Catalogue of the Tortricidae (ver. 3.0). Available from http://www.tortricid.net/catalogue.asp [accessed 26 Nov. 2016].

Guenée A. 1845a. Essai sur une nouvelle classification des microlépidoptères et catalogue des espèces européennes connues jusqu'à jour. Annales de la Société entomologique de France 2 (3): 297-344. Available from https://biodiversitylibrary.org/page/8310469 [accessed 16 Oct. 2017].

Guenée A. 1845b. Europaeorum Microlepidopterorum Index Methodicus, sive Pyrales, Tortrices, Tineae et Alucitae Linnaei, secundum novum naturalemque Ordinem dispositae, Nominibus Genuinis restitutis, Synomimia accurate elucidata, Locis indicatis, novisque Speciebus aut Larvis brevi descriptis. Pars prima: Sistens Tortrices, Phycidas, Crambidas, Tinearumque initiumaut Larvis brevi descriptis. Pars prima: Sistens Tortrices, Phycidas, Crambidas, Tinearumque initium. Roret, Paris, France.

Hebert P.D.N., Cywinska A., Ball S.L. \& de Waard J.R. 2003. Biological identifications through DNA barcodes. Proceedings of the Royal Society B 270: 313-321. https://doi.org/10.1098/rspb.2002.2218 
Hebert P.D.N., de Waard J.R. \& Landry J.-F. 2009. DNA barcodes for 1/1000 of the animal kingdom. Biology Letters 6: 359-362. https://doi.org/10.1098/rsbl.2009.0848

Huemer P. 2015. DNA-Barcoding von Schmetterlingen - alpine Artenvielfalt neu bewertet. Acta ZooBot Austria 152: 161-165.

Huemer P. \& Hebert P.D.N. 2011. Cryptic diversity and morphology of high alpine Sattleria - a case study combining DNA barcodes and morphology (Lepidoptera: Gelechiidae). Zootaxa 2981: 1-22.

Huemer P. \& Mutanen M. 2015. Alpha taxonomy of the genus Kessleria Nowicki, 1864, revisited in light of DNA-barcoding (Lepidoptera, Yponomeutidae). ZooKeys 503: 89-133.

https://doi.org/10.3897/zookeys.503.9590

Kandul N.P., Lukhtanov V.A., Dantchenko A.V., Coleman J.W.S., Sekercioglu C.H., Haig D. \& Pierce N.E. 2004. Phylogeny of Agrodiaetus Hübner, 1822 (Lepidoptera: Lycaenidae) inferred from mtDNA sequences of COI and COII and nuclear sequences of EF1- $\alpha$ : karyotype diversification and species radiation. Systematic Biology 53 (2): 278-298. https://doi.org/10.1080/10635150490423692

Kovács Z. \& Kovács S. 2004. The occurrence of Phtheochroa drenowskyi (Rebel, 1916) (Lepidoptera, Tortricidae, Cochylini) in Romania. Entomologica Romanica 8-9: 39-42.

Lesar T., Habeler H. \& Arenberger E. 2009. Prispevek k poznavanju metuljev (Lepidoptera) Slovenije II: nove vrste metuljčkov (Microlepidoptera). Natura Sloveniae 11 (2): 39-60.

Millière P. 1845. Iconographie et Description de Chenilles et Lépidoptères inédits 2. F. Savy, Paris.

Mutanen M., Hausmann A., Hebert P.D.N., Landry J.-F., de Waard J.R. \& Huemer P. 2012. Allopatry as a Gordian knot for taxonomists: patterns of DNA barcode divergence in arctic-alpine Lepidoptera. PLoS One 7 (10): e47214. https://doi.org/10.1371/journal.pone.0047214

Pazhenkova E.A., Zakharov E.V. \& Lukhtanov V.A. 2015. DNA barcoding reveals twelve lineages with properties of phylogenetic and biological species within Melitaea didyma sensu lato (Lepidoptera, Nymphalidae). ZooKeys 538: 35-46. https://doi.org/10.3897/zookeys.538.6605

Ragonot E.-L. 1894. Notes synonymiques sur les microlépidoptères et description d'espèces peu connues ou inédites. Annales de la Société entomologique de France 63: 161-226. Available from https://biodiversitylibrary.org/page/32549501 [accessed 16 Oct. 2017].

Ratnasingham S. \& Hebert P.D.N. 2007. BOLD: The Barcode of Life Data System (http://www.barcodinglife.org). Molecular Ecology Notes 7: 355-364.

https://doi.org/10.1111/j.1471-8286.2007.01678.x

Ratnasingham S. \& Hebert P.D.N. 2013. A DNA-based registry for all animal species: the Barcode Index Number (BIN) system. PLoS One 8: e66213. https://doi.org/10.1371/journal.pone.0066213

Razowski J. 1970. Cochylidae. In: Amsel H.G., Gregor F. \& Reisser H. (eds) Microlepidoptera Palaearctica 3. Georg Fromme, Vienna, Austria.

Razowski J. 1991a. The catalogue of the species of Tortricidae (Lepidoptera). Part I: Palaearctic Chlidanothinae and Tortricinae: Cochylini, Tortricini, Ceracini, Cnephasiini. Acta Zoologica Cracoviensia 34 (1): 99-162.

Razowski 1991b. Notes on Cochylinae genus Phtheochroa Stephens (Lepidoptera: Tortricidae) with descriptions of new American species. Acta Zoologica Cracoviensia 34 (1): 163-187.

Razowski J. 2002. Tortricidae of Europe. Volume 1. Tortricinae and Chlidanothinae. František Slamka, Bratislava, Slovakia. 
Razowski J. 2008. Tortricidae of the Palaearctic Region. Volume 1. Tortricini and General Part. František Slamka, Bratislava, Slovakia.

Razowski J. 2009. Tortricidae of the Palaearctic Region. Volume 2. Cochylini. František Slamka, Bratislava, Slovakia.

Rebel H. 1916. Beitrag zur Lepidopterenfauna Bulgariens. Verhandlungen der Kaiserlich-Königlichen Zoologisch-Botanischen Gesellschaft in Wien 66: 36-42.

Robinson G. 1976. The preparation of slides of Lepidoptera genitalia with special reference to the Microlepidoptera. Entomologist's Gazette 27: 127-132.

Schawerda K. 1908. Bericht der Sektion für Lepidopterologie. Verhandlungen der KaiserlichKöniglichen Zoologisch-Botanischen Gesellschaft in Wien 58: 250-273.

Tamura K., Stecher G., Peterson D., Filipski A. \& Kumar S. 2013. MEGA6: Molecular Evolutionary Genetics Analysis version 6.0. Molecular Biology and Evolution 30: 2725-2729.

https://doi.org/10.1093/molbev/mst197

Trematerra P. 2003. Catalogue of Lepidoptera Tortricidae of the Italian fauna: geonomy, Italian distribution, biological notes, identification. Bollettino di Zoologia Agraria e di Bachicoltura, Series II, 35 (Suppl.): 1-270.

Varga Z.S. \& Schmitt T. 2008. Types of oreal and oreotundral disjunctions in the western Palearctic. Biological Journal of the Linnean Society 93: 415-430.

https://doi.org/10.1111/j.1095-8312.2007.00934.x

Zlatkov B. 2011. A preliminary study of everted vesicae of several leafrollers (Tortricidae). Nota Lepidopterologica 33: 285-300. Available from https://biodiversitylibrary.org/page/46832594 [accessed 16 Oct. 2017].

Zlatkov B. \& Huemer P. 2016. Phtheochroa unionana (Kennel, 1900) recognised as a dimorphic Cochylini species, with description of the hitherto unknown male genitalia (Lepidoptera, Tortricidae). Nota Lepidopterologica 39 (2): 113-121. https://doi.org/10.3897/n1.39.9050

Manuscript submitted: 3 February 2017

Manuscript accepted: 16 May 2017

Manuscript published: 21 November 2017

Topic editor: Gavin Broad

Desk editor: Danny Eibye-Jacobsen

Printed versions of all papers are also deposited in the libraries of the institutes that are members of the EJT consortium: Muséum national d'Histoire naturelle, Paris, France; Botanic Garden Meise, Belgium; Royal Museum for Central Africa, Tervuren, Belgium; Natural History Museum, London, United Kingdom; Royal Belgian Institute of Natural Sciences, Brussels, Belgium; Natural History Museum of Denmark, Copenhagen, Denmark; Naturalis Biodiversity Center, Leiden, the Netherlands; Museo Nacional de Ciencias Naturales-CSIC, Madrid, Spain; Real Jardín Botánico de Madrid CSIC, Spain. 